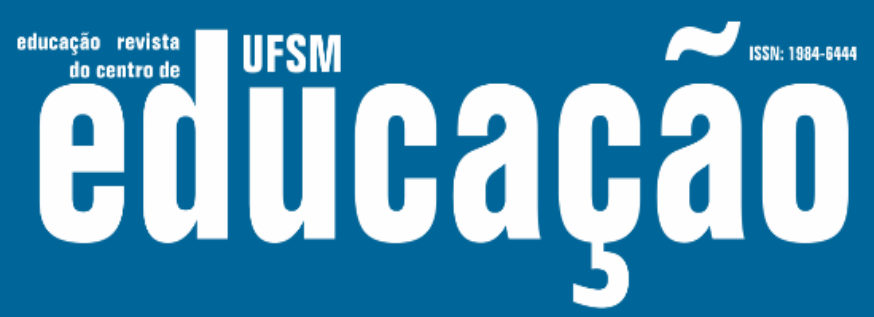

ISSN: 1984-6444 | http://dx.doi.org/10.5902/1984644439560

\title{
Percepções dos professores de biologia sobre a avaliação em larga escala em Portugal e Brasil
}

Biology teachers' perceptions of large-scale assessment in Portugal and Brazil

Percepciones del profesor de biología sobre la evaluación a gran escala en Portugal y Brasil

Daisy da Silva

Servidora pública federal, no Instituto Federal Catarinense, Blumenau, Santa Catarina, Brasil. daisy.silva@ifc.edu.br - http://orcid.org/0000-0001-5481-1851

Maria da Piedade Simões Santana Pessoa Vaz Rebelo

Professora doutora da Universidade de Coimbra. Portugal.

pvaz@mat.uc.pt - https://orcid.org/0000-0003-0843-0200

Cristina Maria Moreira Monteiro Leal Canhoto

Professora doutora da Universidade de Coimbra. Portugal. ccanhoto@ci.uc.pt - https://orcid.org/0000-0003-3343-8757

Recebido em 14 de outubro de 2019

Aprovado em 24 de outubro de 2019

Publicado em 31 de janeiro de 2020

\section{RESUMO}

Os Exames Nacionais têm grande implicação nas políticas educacionais, na vida de alunos, pais e professores e também no processo educativo. Neste sentido, o propósito deste artigo é apresentar as percepções dos professores de Biologia do Brasil e de Portugal, em relação aos impactos dos Exames Nacionais na sua prática docente. Houve a recolha de dados através de questionário, aplicado a 29 professores de escolas em Portugal e 32 do Brasil. Em ambos os países, os professores percebem o Exame como instrumento normalizador tanto da prática pedagógica quanto de um tipo de formação acadêmica padronizada, com um currículo desenhado para determinados conteúdos. Os resultados indicam que as "avaliações em larga escala", tanto em Portugal quanto no Brasil, impactam sobre as práticas pedagógicas dos professores da disciplina Biologia.

Palavras-chave: Prática pedagógica; Exames Nacionais; Avaliação em larga escala.

\section{ABSTRACT}

The National Examinations have great implication in the educational policies in the life of students, parents and teachers and also in the educational process. In this sense, 


\section{Aitloabão}

ISSN: 1984-6444 | http://dx.doi.org/10.5902/1984644439560

the purpose of this article is to present the perceptions of biology teachers from Brazil and Portugal, regarding the impacts of National Exams on their teaching practice. Data were collected through a questionnaire, applied to 29 school teachers in Portugal and 32 from Brazil. In both countries, teachers perceive the Exam as a normalizing instrument of both pedagogical practice and as a standardized academic formation, with a curriculum designed for certain contents. Results indicate that "large-scale assessments", both in Portugal and in Brazil, impact on the pedagogical practices of the professors of the discipline biology.

Keywords: Pedagogical practices; National Examinations; Large scale assessments.

\section{RESUMEN}

Los exámenes nacionales tienen implicaciones importantes para las políticas educativas, la vida de los estudiantes, padres y maestros, así como el proceso educativo. En este sentido, el propósito de este artículo es presentar las percepciones de los profesores de biología de Brasil y Portugal, con respecto al impacto de los Exámenes Nacionales en su práctica docente Los datos fueron recolectados a través de un cuestionario, aplicado a 29 maestros de escuela en Portugal y 32 de Brasil. En ambos países, los profesores perciben el Examen como un instrumento normalizador tanto para la práctica pedagógica como para un tipo de formación académica estandarizada, con un plan de estudios diseñado para cierto contenido. Los resultados indican que las "evaluaciones a gran escala", tanto en Portugal como en Brasil, impactan en las prácticas pedagógicas de los profesores de biología.

Palabra Clave: Profesor de Biología; Práctica pedagógica; Exámenes Nacionales.

\section{Introdução}

Desde que foram criados os Exames Nacionais e instituídos os rankings das melhores escolas, parece que se criou um axioma na educação, de que somente os professores é que não são capazes (ou o são) de promover uma boa (ou má) aprendizagem. Os Exames Nacionais têm uma grande implicação nas políticas educacionais, na vida de alunos, pais e professores e também no processo educativo (a maneira de ensinar, a maneira de avaliar, os conteúdos ministrados, etc.).

Em Portugal, o Exame Nacional é aplicado aos alunos no final do $11^{\circ}$ ou $12^{\circ}$, em duas fases distintas, em cada um dos anos. O Exame tem o peso de $30 \%$ do valor da nota final do aluno; assim sendo, todos os alunos para obterem a certificação do ensino médio têm que realizar a prova. A prova a ser realizada pelo aluno depende 


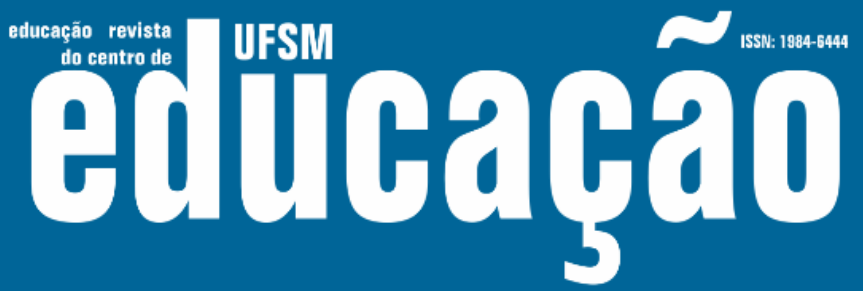

ISSN: 1984-6444 | http://dx.doi.org/10.5902/1984644439560

do curso ao qual se pretende candidatar no Ensino Superior (Decreto-Lei № 17/2016, de 4 de abril do Ministério da Educação e Ciência, 2016).

Já no Brasil, o ENEM não tem caráter obrigatório; criado em 1998 pelo Ministério da Educação (MEC), sofreu sua primeira alteração em 2009, por meio da Portaria №109, de 27 de maio de 2009, que em seu Art. $2^{\circ}$ ampliou os objetivos do Exame, passando estes a serem: (I) autoavaliação; (II) seleção para o mundo do trabalho; (III) seleção para continuidade nos estudos; (IV) meio de participação em programas governamentais; (V) certificação para jovens e adultos no nível de conclusão do ensino médio; avaliação de (VI) escolas e (VII) alunos (INEP, 2009). O ENEM está entre os maiores Exames do mundo. A edição de 2018 teve um total de 5.513.662 milhões de inscritos. A aplicação das provas ocorre em dois dias: no primeiro as provas referem-se a Linguagens, Códigos e suas Tecnologias, Redação e Ciências Humanas e suas Tecnologias. No segundo dia, Ciências da Natureza e suas Tecnologias e Matemática e suas Tecnologias.

É possível perceber que há uma complexa rede de componentes e fatores subjacente aos Exames e que este apresenta componentes nem sempre tão óbvias. No que concerne as práticas pedagógicas, Marinho; Fernandes e Leite (2014, p. 151) mencionam que "a avaliação assume papel estruturador dos processos de ensino e aprendizagem e do trabalho dos professores e dos alunos". Nesse sentido, pode colocar-se a seguinte questão: Qual o impacto dos "Exames em larga escala", em Portugal e no Brasil, sobre as práticas de ensino e avaliação dos professores da disciplina Biologia?

$\mathrm{Na}$ intenção de responder a este questionamento, neste artigo, apresentam-se as percepções dos professores de Biologia, do Brasil e de Portugal, em relação aos impactos dos Exames Nacionais na sua prática docente. Com esta finalidade, o trabalho se desenvolveu de acordo com os seguintes objetivos específicos: a) identificar as práticas e estratégias pedagógicas utilizadas, por um grupo de professores tanto de Portugal quanto no Brasil, para ensinar e avaliar na disciplina Biologia e b) caracterizar a preocupação dos professores em preparar seus alunos para o Exame Nacional. Assim sendo, entende-se que a definição dos objetivos de aprendizagem podem ser melhor alinhavados, ao serem identificadas e 


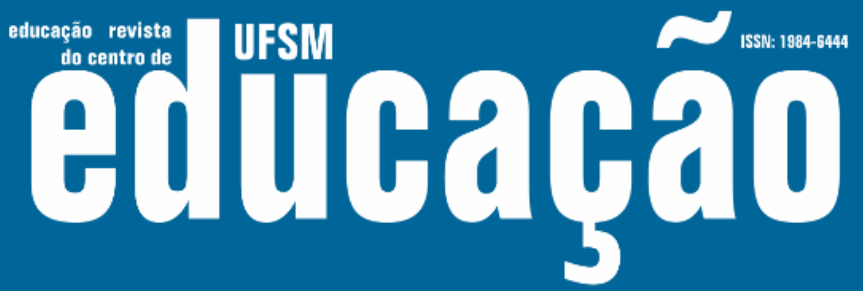

ISSN: 1984-6444 | http://dx.doi.org/10.5902/1984644439560

caracterizadas as práticas e estratégias pedagógicas dos professores e sua relação com os Exames Nacionais.

\section{Metodologia}

\section{Procedimentos}

Os dados foram recolhidos através de um questionário aplicado, nos anos de 2017 e 2018, aos professores de escolas de ensino médio de Portugal e Brasil. A coleta de dados deu-se tanto de forma presencial quanto virtual. Esta última foi disponibilizada para proporcionar a participação de indivíduos oriundos de todo o território e para conferir liberdade para que respondessem no horário que lhes fosse mais conveniente. $\mathrm{O}$ contato com os respondentes online ocorreu através de e-mails enviados para Associação de Professores de Biologia e Geologia (APPBG), para as direções das escolas de ensino médio de Coimbra e para professores de Biologia de escolas públicas e privadas no estado de Santa Catarina/Brasil. Nestes e-mails, além de disponibilizar o link do questionário virtual, também constava o objetivo e propósito do mesmo, bem como o esclarecimento de que a realização do referido inquérito havia sido autorizada pela Comissão Nacional de Proteção de Dados (CNPD), no caso de Portugal. No Brasil, os questionários online não precisam de autorização oficial, apenas aceitação do próprio respondente.

Ao acessar ao link, o respondente era direcionado para o formulário eletrônico disponível no Google Forms. Precedendo ao início do questionário, foi inserido um Termo de Consentimento Livre e Esclarecido (TCLE) virtual, composto por esclarecimentos sobre a pesquisa, além da solicitação de autorização para o uso dos dados. O questionário aplicado foi de tipo misto, ou seja, apresentou questões de resposta aberta e de resposta fechada. As questões foram elaboradas de forma a atender adequadamente aos objetivos da pesquisa. Assim, o questionário foi dividido em três blocos. O primeiro bloco inicia-se com uma solicitação e agradecimento pelo preenchimento do questionário, abordando os motivos de sua realização. Seguem-se questões relativas à caracterização do respondente. Finalizando este bloco, as questões passam a ter o propósito de saber quais os conhecimentos, opiniões e 


\section{Autดaคูão}

ISSN: 1984-6444 | http://dx.doi.org/10.5902/1984644439560

concepções do docente sobre os Exames. No segundo bloco, pretendem-se conhecer as práticas pedagógicas desenvolvidas pelo docente para ensinar os conteúdos e analisar eventuais interferências do Exame Nacional e ENEM nessas práticas. No terceiro e último bloco as questões foram elaboradas com o objetivo de correlacionar a influência do Exame Nacional e ENEM na prática avaliativa.

Antes da aplicação do questionário, foi realizado um pré-teste para obter informações sobre a clareza e compreensão do mesmo, bem como para evidenciar possíveis falhas na sua redação. Assim, foi possível realizar ajustes na formulação de algumas perguntas.

A tabulação e análise dos dados referentes aos questionários foram feitas com recurso ao Excel. O propósito desta análise foi o de buscar padrões ou tendências que auxiliaram nas inferências relativas ao assunto.

\section{Participantes}

Participaram no estudo professores da disciplina Biologia-Geologia (Portugal) e Biologia (Brasil) de escolas públicas e privadas, envolvidos direta ou indiretamente no processo de avaliação externa, ou seja, possuem características essenciais à população amostrada. Em Portugal, 29 professores do grupo de recrutamento 520 (Biologia e Geologia) em exercício nas escolas responderam ao questionário e, no Brasil foram 32 professores de Biologia respondentes.

Em relação ao tempo de serviço dos professores Portugueses, 38\% tinham mais de 30 anos de serviço e outros $24 \%$ tinham entre 26 e 30 anos de tempo de serviço, o que revela uma amostra composta por professores experientes profissionalmente. Em relação à formação acadêmica, predomina a licenciatura (72\%), seguido de $21 \%$ com mestrado e $7 \%$ com doutorado. Dos 29 professores de Portugal, apenas um lecionava além da escola pública, numa escola privada, os demais lecionavam apenas em escola pública. Em relação ao período de trabalho, apenas 2 professores trabalhavam no período matutino; os demais 27 trabalhavam em período integral. O percentual de professores por idade, pode ser verificado na figura 1. 


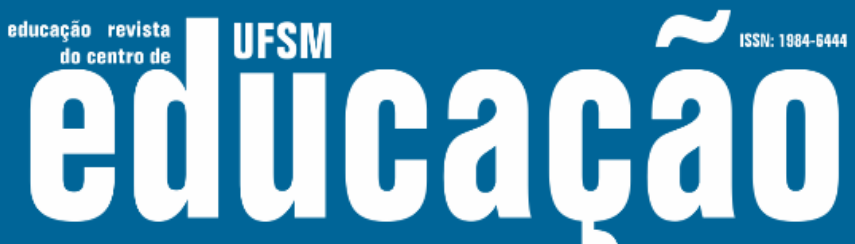

ISSN: 1984-6444 | http://dx.doi.org/10.5902/1984644439560

Figura 1 - Caracterização etária dos professores de Biologia-Geologia entrevistados em Portugal.

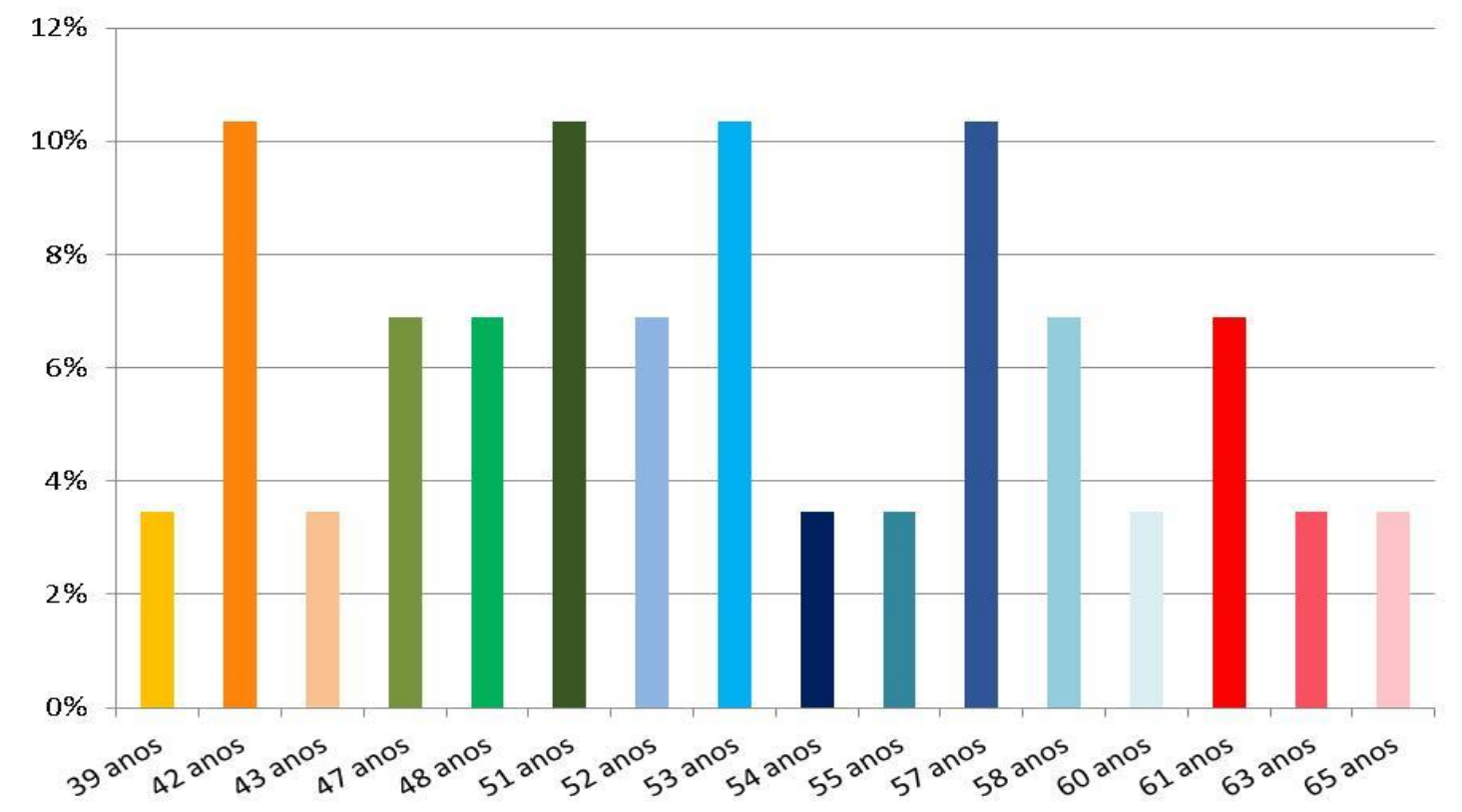

Fonte: elaborado pelas autoras

Em relação ao tempo de serviço dos professores Brasileiros, apenas $6 \%$ tinham mais de 30 anos de serviço. Provavelmente esse fato está ligado a formação acadêmica, pois $50 \%$ dos 32 entrevistados têm doutorado e $28 \%$ mestrado, o que representa $78 \%$ dos entrevistados. Este fato reflete-se na vida profissional destes professores, pois, uma maior qualificação demanda mais tempo na vida acadêmica e, portanto, menor experiência. Interessante notar que apenas 1 professor possui apenas a licenciatura, 5 possuem especialização e uma professora é mestranda. Em relação à escola em que lecionam, a grande maioria (84\%) trabalha exclusivamente em instituição pública e 15\% em escolas privadas, sendo que destes, $6 \%$ lecionam tanto em escola pública quanto em privada. Em relação ao período em que trabalhavam, $6 \%$ professores lecionam apenas no período matutino e $6 \%$ no período noturno; os demais $87 \%$ trabalham em período integral. O percentual de professores por idade pode ser verificado na figura 2. 


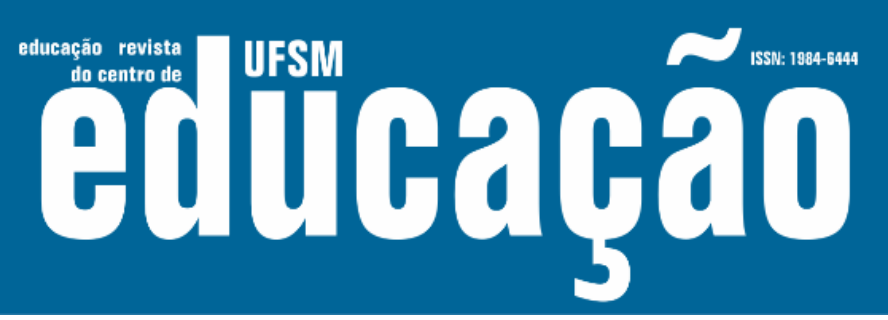

ISSN: 1984-6444 | http://dx.doi.org/10.5902/1984644439560

Figura 2 - Caracterização etária dos professores de Biologia entrevistados no Brasil.

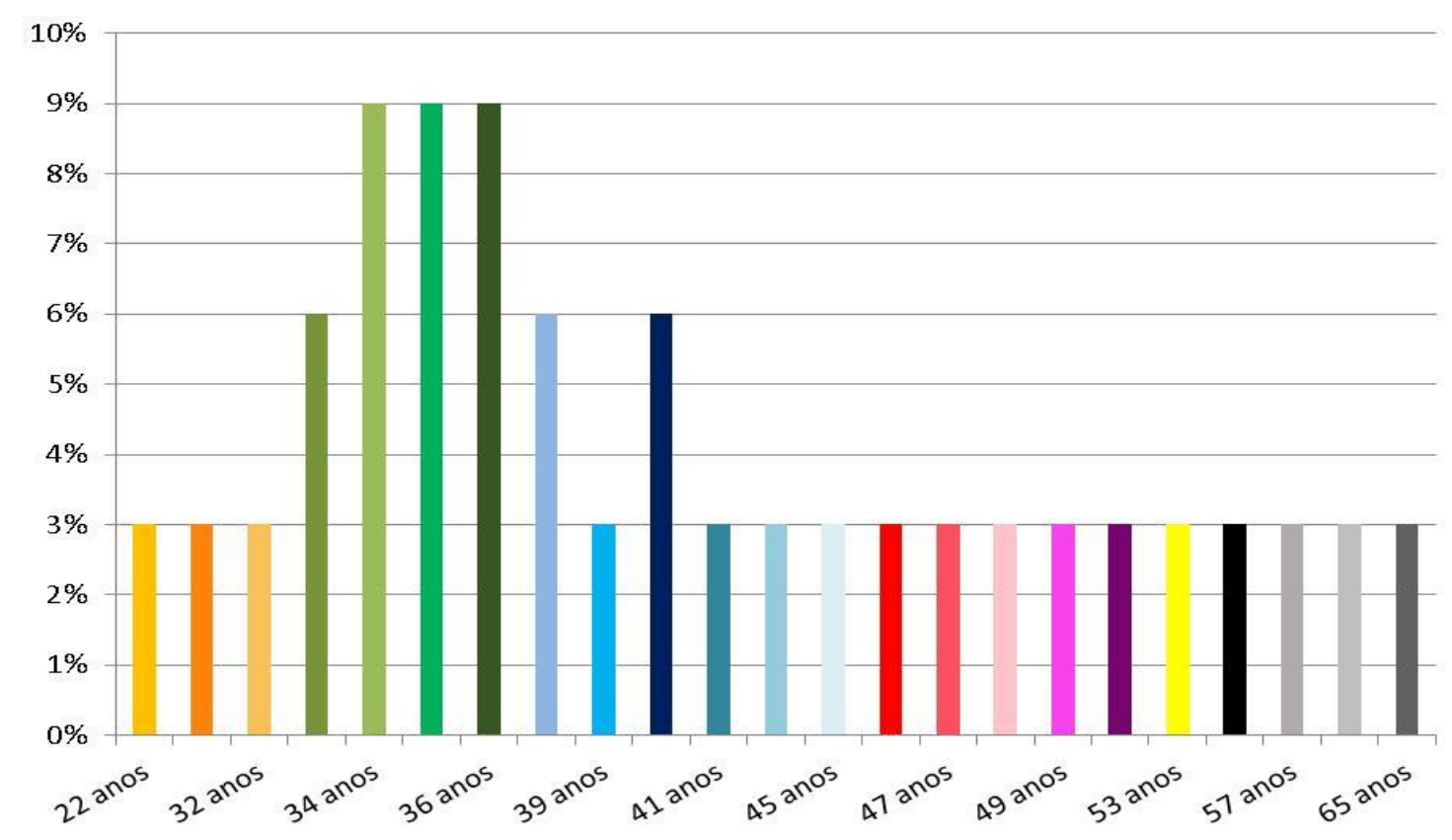

Fonte: elaborado pelas autoras

\section{O que pensam os professores de Biologia-Geologia sobre o Exame Nacional de Portugal}

Relativamente ao Exame Nacional, questionou-se aos professores se o consideravam como uma boa forma de avaliar o percurso escolar do aluno do ensino médio. Na figura 3 , pode-se verificar que $80 \%$ dos professores consideram que o Exame Nacional é "em parte" uma boa forma de avaliar o percurso escolar do aluno.

Figura 3: Importância do Exame Nacional na avaliação do percurso escolar dos alunos portugueses

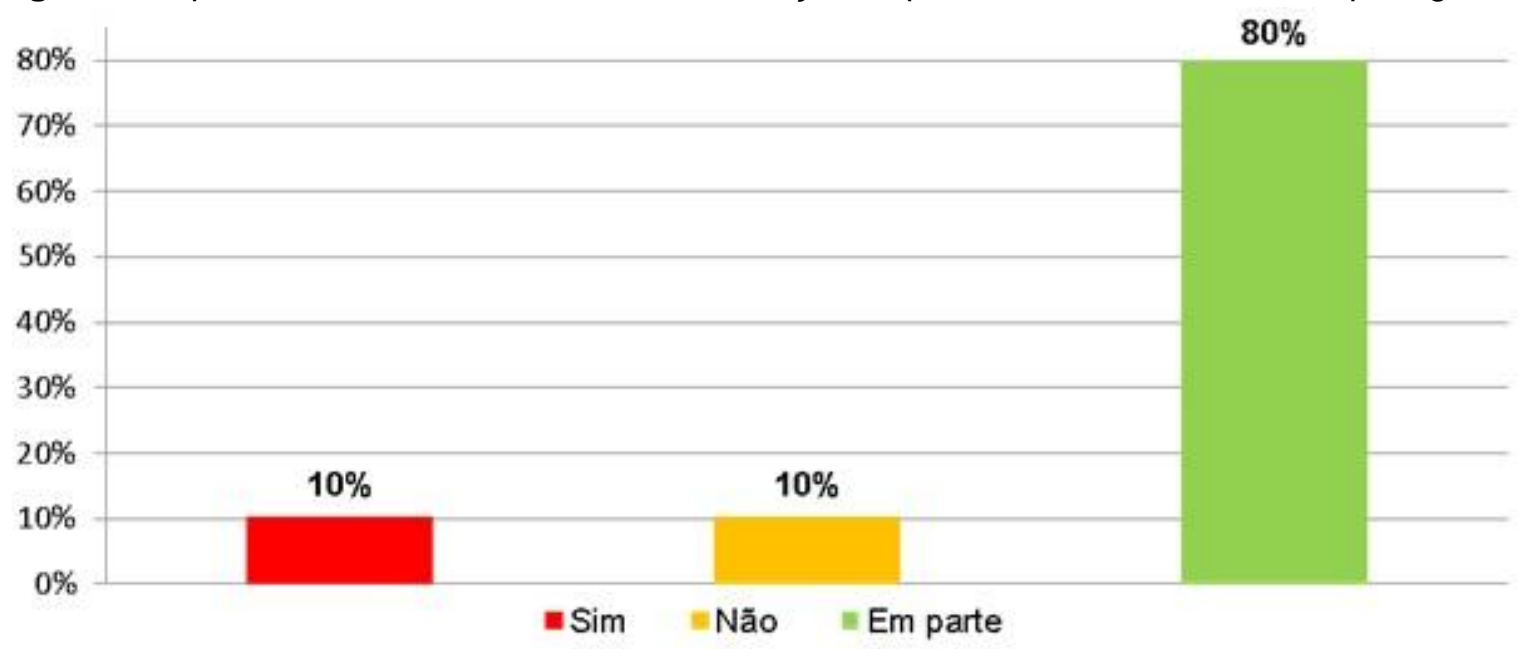

Fonte: elaborado pelas autoras 


\section{Eitha \\ ISSN: 1984-6444}

ISSN: 1984-6444 | http://dx.doi.org/10.5902/1984644439560

Face ao fato de a maioria dos professores terem respondido que, em parte, os Exames Nacionais avaliam o percurso escolar do aluno, passamos a analisar a questão seguinte: "Na sua opinião, qual a importância do Exame Nacional na formação dos alunos?" As respostas apresentadas na figura 4, mostram que $26 \%$ dos professores acreditam que o Exame Nacional ajuda aos alunos na capacidade de interpretar informação complexa e $12 \%$ na capacidade reestruturar informação complexa. Com $10 \%$ encontramos empatadas a capacidade de simplificar informação complexa e o acesso a Universidade. Apenas 2\% dos professores participantes no estudo consideram que o Exame Nacional ajuda os alunos na capacidade de tomar de decisões.

Figura 4: Opinião dos professores sobre a importância do Exames Nacionais na formação dos alunos

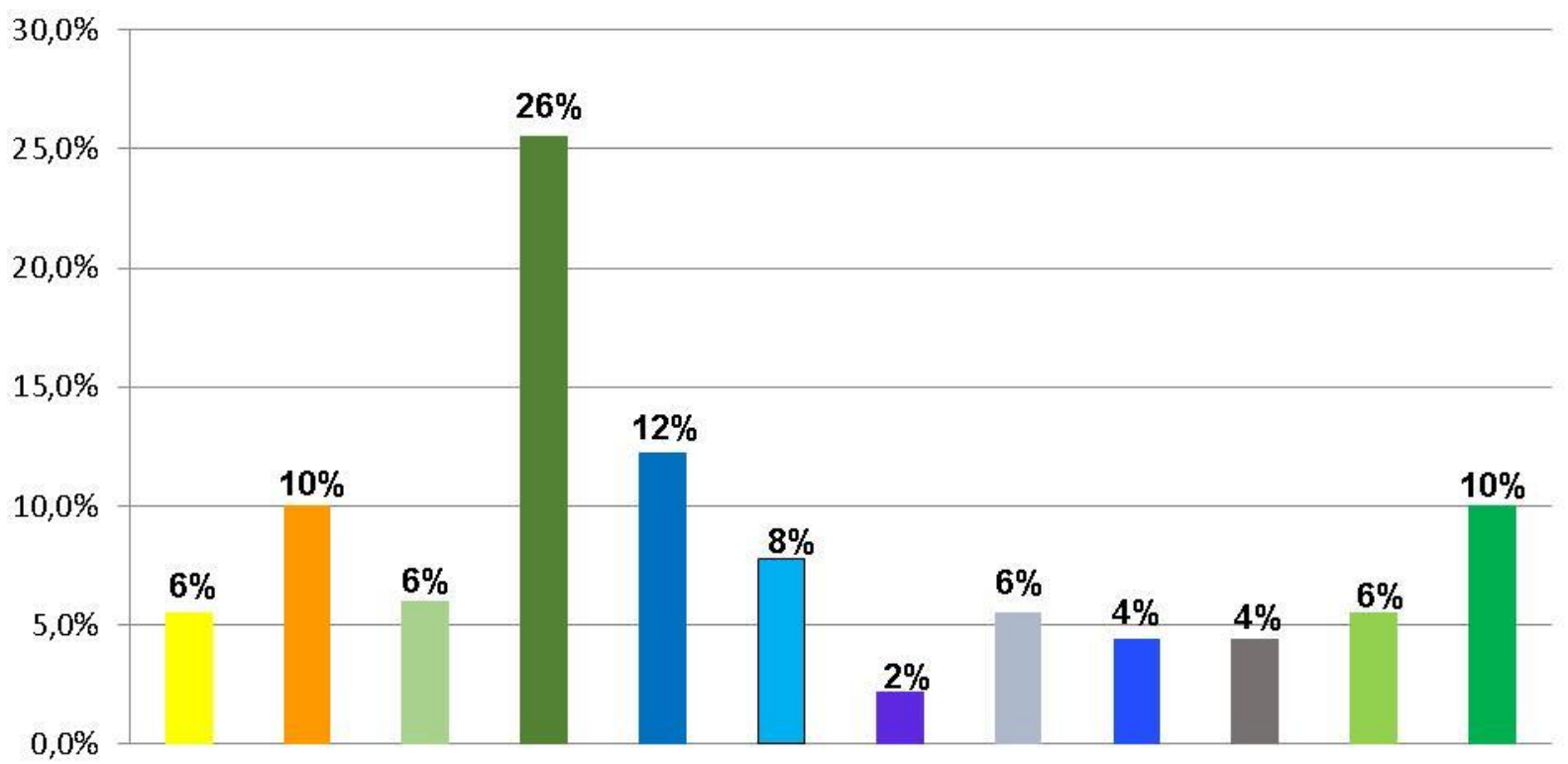

No desenvolvimento do pensamento crítico - Na capacidade de simplificar informação complexa

- Na capacidade de ordenar informação complexa

- Na capacidade de interpretar informação complexa

- Na capacidade reestruturar informação complexa

$\square$ No dominio dos procedimentos experimentais

- Na capacidade de tomar decisões

- Na possibilidade de relacionar os conteúdos da escola com o cotidiano

- No desenvolvimento de diferentes linguagens

- Estimulando o desenvolvimento de atitudes de responsabilizaçã pessoal e social

Na memorização

- Ao acesso a Universidade

Fonte: elaborado pelas autoras 


\section{Autดaคูão}

ISSN: 1984-6444 | http://dx.doi.org/10.5902/1984644439560

Apesar de a maioria dos professores considerarem que o Exame Nacional consegue apenas, em parte, avaliar o percurso escolar do aluno, esses mesmos professores atribuem ao Exame Nacional a capacidade de ajudar os alunos na capacidade de interpretar (26\%) e reestruturar (12\%) informações complexas e de simplificar essa informação (10\%). A mesma percentagem é atribuída à conviç̧ão de que o Exame auxilia os alunos no acesso a Universidade. As respostas parecem divergentes, entretanto, essa maneira de pensar dos professores parece estar ligada a uma interpretação de que os alunos devem se adaptar à alta exigência das provas dos Exames e, portanto, ajuda-os a adquirir novos conhecimentos.

Ainda sobre as percepções dos professores a respeito dos impactos do Exame Nacional, questionou-se sobre a tomada de conhecimento das médias (Rankings) obtidas pela escola em que leciona, especificamente na disciplina de BiologiaGeologia. A maioria dos professores $(93 \%)$ responderam que têm conhecimento dessas médias. Neste âmbito, recorreu-se à pergunta "Considera que a média divulgada corresponde à realidade da sua escola?" $38 \%$ dos professores têm a visão de que os rankings não correspondem à realidade da sua escola e $62 \%$ acreditam que sim.

$\mathrm{Na}$ opinião dos professores que acreditam que os rankings não correspondem à realidade da sua escola, isso ocorre porque "O Exame não avalia todo o tipo de competências desenvolvidas pelos alunos na minha escola" (P4). Ou ainda, "Porque é impossível avaliar em duas horas e meia todo o trabalho realizado ao longo dos anos" (P23). Um dado que corrobora com a opinião destes professores é a divulgação das classificações obtidas nas provas aplicadas na escola e a média obtida nas provas finais nacionais: as denominadas classificação de Exame (CE) e classificação interna final (CIF). Segundo o relatório de 2017 do Júri Nacional de Exames (JNE), a disciplina de Biologia e Geologia (702) está entre as disciplinas com maior diferença entre CE e CIF, sendo de 5,0 (cinco) valores para o ano de 2015, 3,9 (três virgula nove) valores no ano de 2016 e 2017.. (MARQUES et al., 2018, p.75).

No relatório de 2017, destaca-se também "o facto de que se trata de resultados referentes a dois tipos de avaliação distintos e que se desenvolvem em contextos 


\section{T-I Usm

ISSN: 1984-6444 | http://dx.doi.org/10.5902/1984644439560

diferentes, com objetivos, periodicidade e instrumentos de avaliação necessariamente diferentes." (MARQUES et al., 2018, p. 75), referido ainda:

Trata-se de comparar a avaliação externa das aprendizagens, que é pontual e feita num contexto nacional, com a avaliação interna, que é contínua, realizada a nível de cada escola e que pretende também avaliar outro tipo de aprendizagens e conhecimentos, não avaliáveis por uma prova escrita. (MARQUES et al., 2018, p. 75).

Compreender que os aspectos das duas avaliações (interna e externa) supracitados são, em parte, os responsáveis pela discrepância das CE e CIF e, conforme menciona o relatório do júri nacional "constitui-se como um indicador de grande importância para o estudo das condições do sistema educativo nas disciplinas do ensino secundário" (MARQUES et al., 2018, p.75).

\section{As influências do Exame nacional, nos professores de biologia- geologia, em Portugal}

\section{Práticas e estratégias pedagógicas}

Visando o conhecimento de práticas e estratégias pedagógicas usadas pelos professores participantes no estudo, foi colocada a questão "Considera que o Exames Nacionais promove mudanças ao nível dos processos de ensino e aprendizagem?". Para $86 \%$ dos professores indagados, a resposta foi afirmativa. Dentre os que responderam afirmativamente, $41 \%$ mencionaram que as mudanças ocorreram na prática do professor e, empatados com $26 \%$, encontramos alterações no processo de aprendizagem dos alunos e alterações na formulação de competências e objetivos educativos (figura 5). 


\section{Usis Eutlaghã}

ISSN: 1984-6444 | http://dx.doi.org/10.5902/1984644439560

Figura 5: Opinião dos professores sobre as mudanças promovidas pelo Exame Nacional nos processos de ensino e aprendizagem

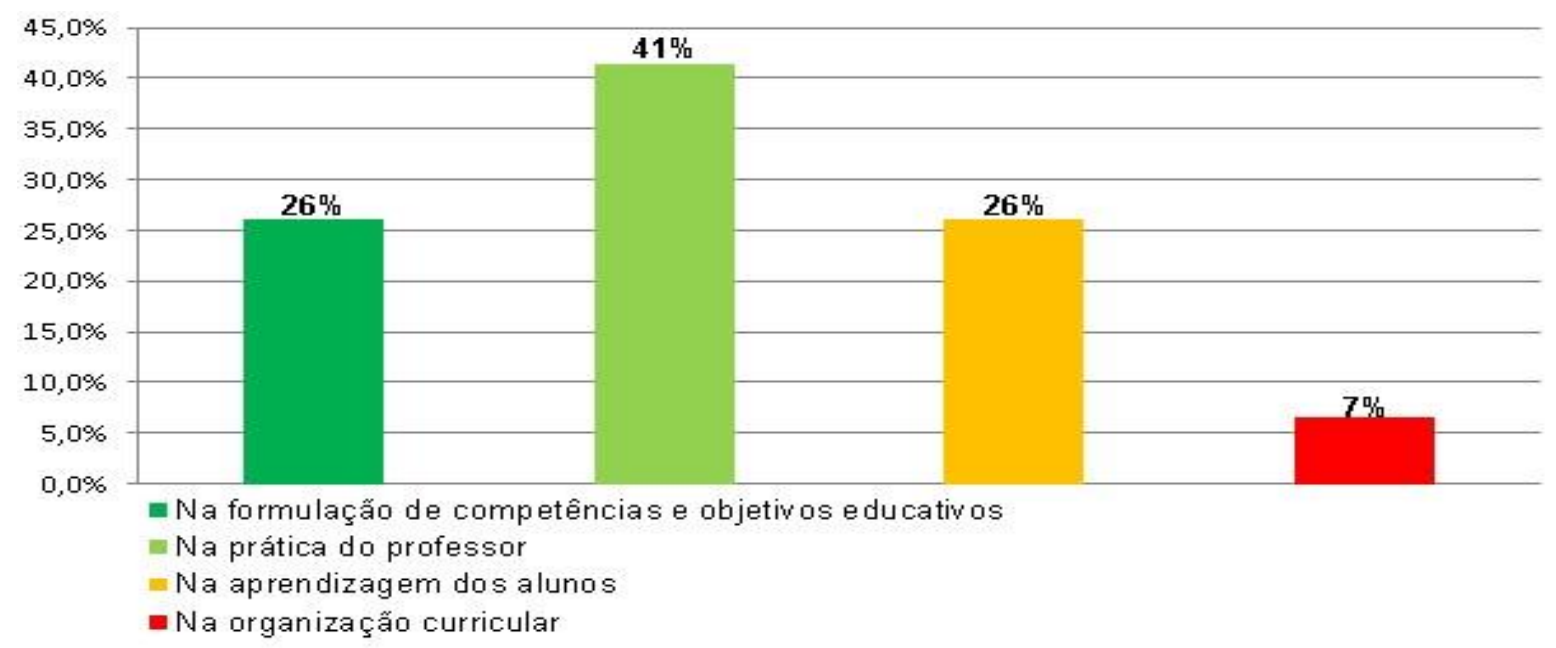

Fonte: elaborado pelas autoras

Logo em sequência ao questionamento supracitado, os professores foram confrontados com a questão "O Exame Nacional influenciou ou tem influenciado a sua prática?". A maioria (97\%) dos professores responderam que sim, ou seja, admitiram que os Exames Nacionais influenciavam sua própria prática pedagógica. Perante a resposta afirmativa, o professor deveria esclarecer como se exercia essa influência na sua prática. A figura 6 ilustra as respostas. É aqui importante destacar que 44\% deles mencionam influência na forma de trabalhar os conteúdos na aula e $30 \%$ no processo de avaliação. Percentagens inferiores foram observadas em termos de influência nos objetivos de ensino da disciplina (15\%) e escolha dos conteúdos (11\%). 


\section{DIFSM entuahá}

ISSN: 1984-6444 | http://dx.doi.org/10.5902/1984644439560

Figura 6: Opinião dos professores sobre como os Exames Nacionais exerce influência na sua prática docente.

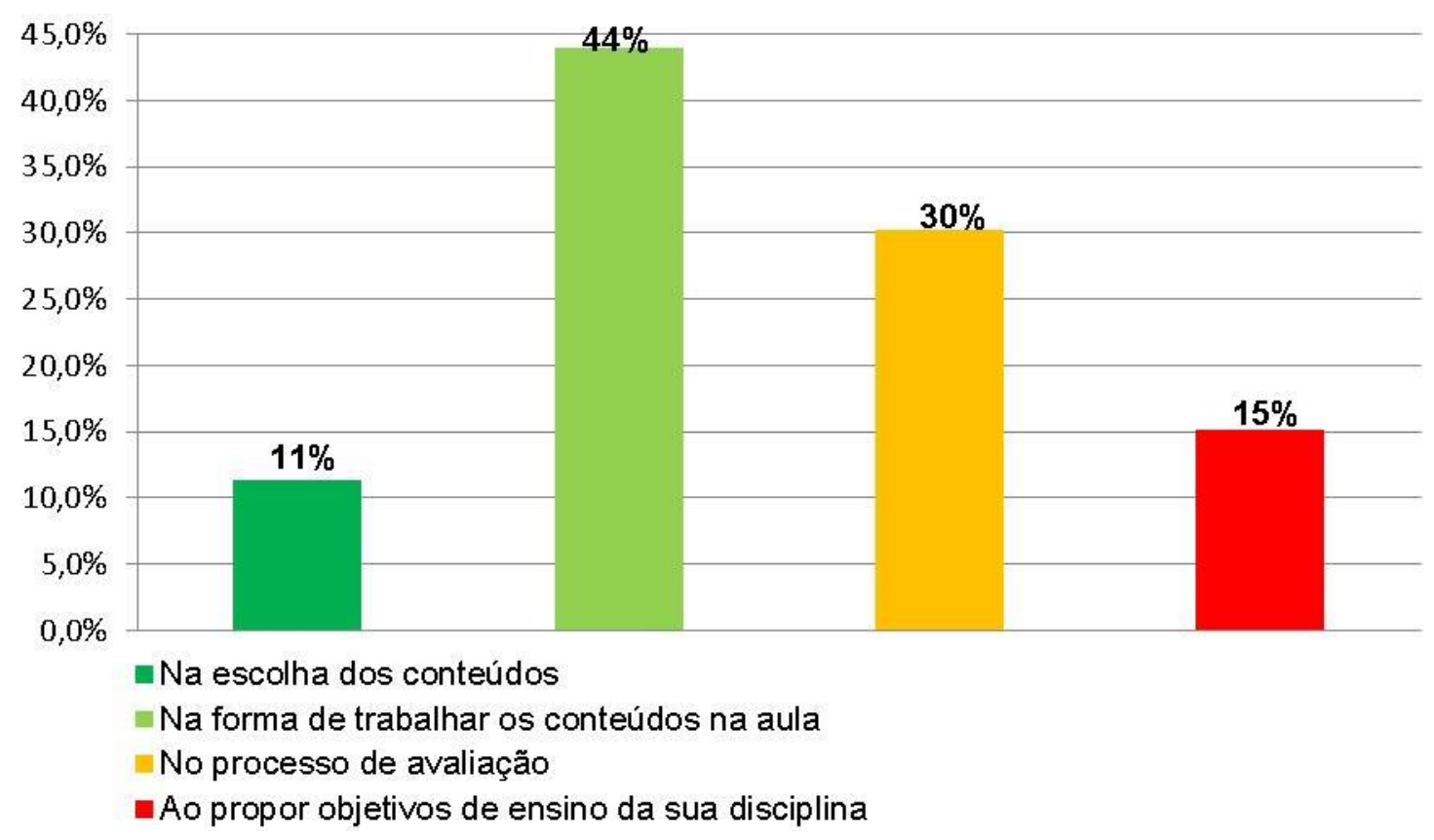

Fonte: elaborado pelas autoras

De uma forma resumida, os resultados expressos na figura 6 apontam para mudanças na prática do professor e consequentemente na aprendizagem dos alunos promovidas pela existência do Exame. Nessa perspectiva, 93\% dos professores admitiram utilizar, em sala de aula, questões do Exame Nacional como método de ensino e no intuito de prepará-los para o Exame (figura 7). Apenas 7\% dos entrevistados disseram não utilizar esta prática.

Corroborando com os resultados aqui encontrados, Lemos, Ribeiro e Rocha, realizaram um inquérito com o objetivo de relacionar a perspectiva tanto dos alunos, quanto dos docentes de Geografia, da Escola de ensino médio António Nobre (Porto), sobre os Exames Nacionais. Constataram que $90 \%$ da amostra respondeu afirmativamente à questão "Os instrumentos de avaliação versam as questões de Exame?". Os autores mencionam também que "os alunos consideram que de fato há uma grande preocupação e esforço por parte dos docentes em adaptar as suas aulas e os conteúdos curriculares da disciplina, bem como o método de avaliação da mesma, aos requisitos dos Exames Nacionais" (LEMOS, RIBEIRO e ROCHA, 2017, 


\section{ح

ISSN: 1984-6444 | http://dx.doi.org/10.5902/1984644439560

p. 41). Na perspectiva dos professores o Exame "Condiciona a preparação de aulas e o normal funcionamento do ano letivo" (p.43). Neste contexto, Flores menciona:

"A cultura performativa dominante tem repercussões na atuação curricular e pedagógica dos professores que passa a ser fortemente orientada por e para resultados, que são procurados por pais, escolas, governos, media, etc., destacando-se sobretudo a dimensão sumativa de avaliação" (FLORES, 2017, p. 9).

Figura 7: Percentagem de professores que admitiram utilizar, em sala de aula, questões do Exame Nacional como método de ensino e preparação para o Exame

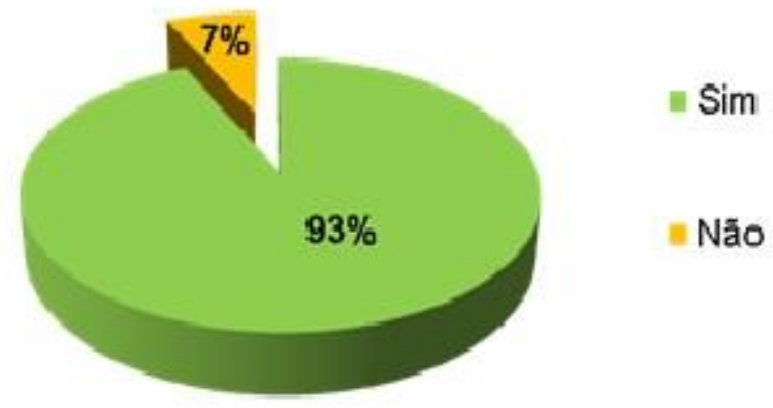

Fonte: elaborado pelas autoras

Relativamente as práticas avaliativas, 69\% dos professores afirmaram que elas mudaram com o estabelecer do Exame Nacional. E, no que diz respeito a estas práticas, os mesmos foram estimulados a responder em que aspectos mudaram. A figura 8 representa graficamente o resultado obtido nesta questão. 


\section{EItha \\ 1SSN: 1984-6444

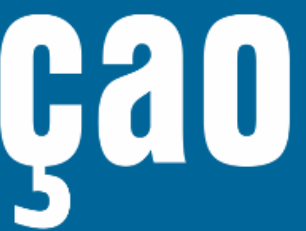

ISSN: 1984-6444 | http://dx.doi.org/10.5902/1984644439560

Figura 8: Mudanças nas práticas avaliativas devido aos Exame Nacional

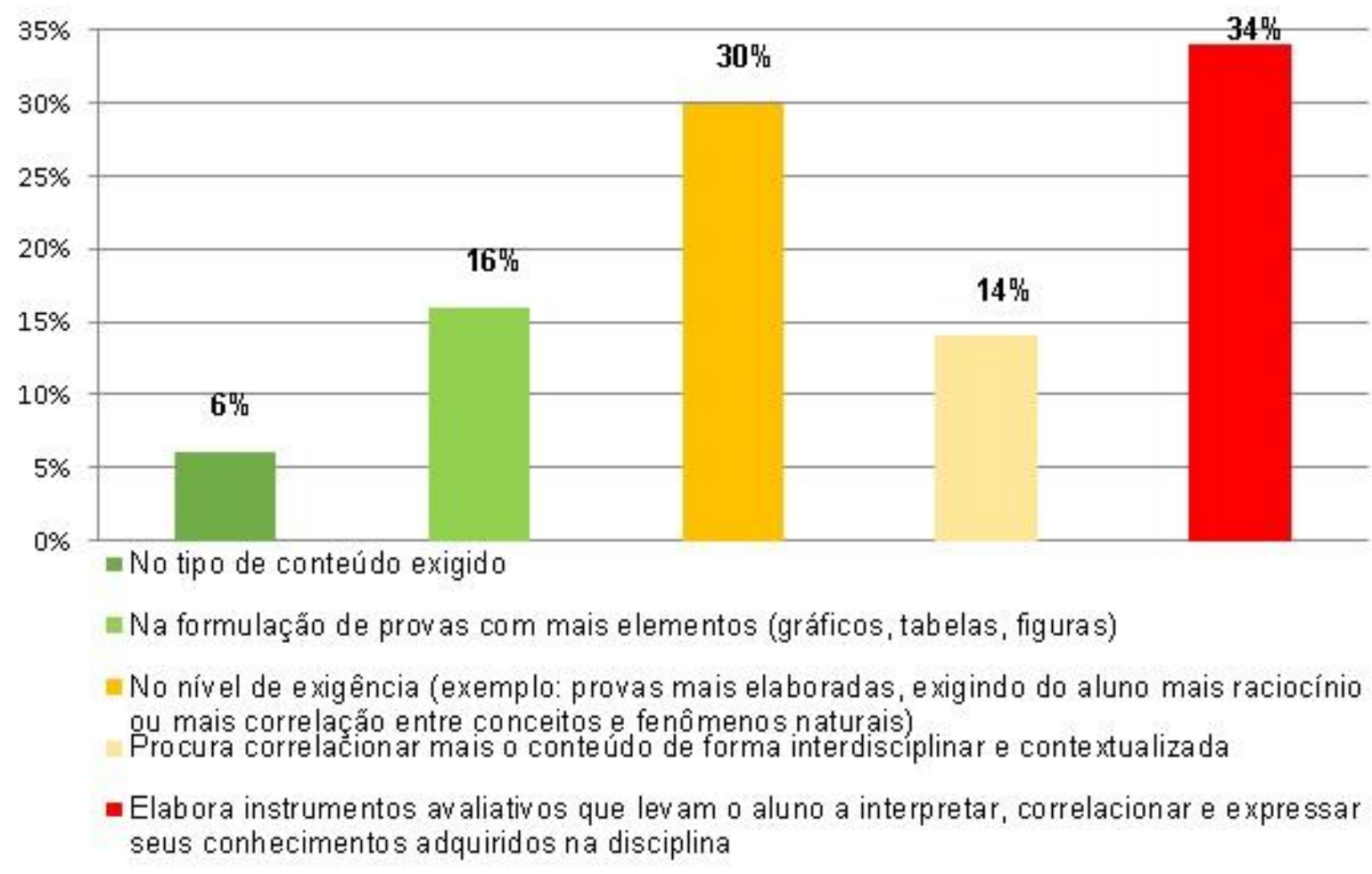

Fonte: elaborado pelas autoras

O gráfico apresentado na figura 8 revela que as mudanças se deram principalmente na elaboração de instrumentos avaliativos que levam o aluno a interpretar, correlacionar, e expressar seus conhecimentos adquiridos na disciplina (34\%) e no nível de exigência (30\%). Neste âmbito, verificam-se as implicações do Exame Nacional na prática docente, constatando-se que ocorreram mudanças nos instrumentos avaliativos, tanto no formato quanto no nível de exigência das provas aplicadas pelos professores respondentes desta pesquisa. Percebe-se também que a avaliação é vista, por si só, como promotora de aprendizagens.

Em termos do tipo de avaliação, a figura 9 revela que $31 \%$ dos professores recorrem à prova escrita com questões de múltipla escolha $\mathrm{e}$ itens de construção/discursivas. Com um percentual de $27 \%$ está o comportamento dos alunos, seguido dos relatórios de experimentação com 17\% e trabalhos em dupla com 11\%. Com menores índices encontramos a prova oral com 7\%. Seminários, provas escritas apenas com questões de escolha múltipla e trabalhos de pesquisa e/ou grupo 


\section{Gllöbarão}

ISSN: 1984-6444 | http://dx.doi.org/10.5902/1984644439560

e/ou trabalho prático com $2 \%$. Com $1 \%$ observa-se a participação oral. Percebe-se nestes resultados o enfoque numa avaliação com a finalidade de classificar e manter o controle sobre os alunos.

Figura 9: Práticas avaliativas utilizadas pelos professores

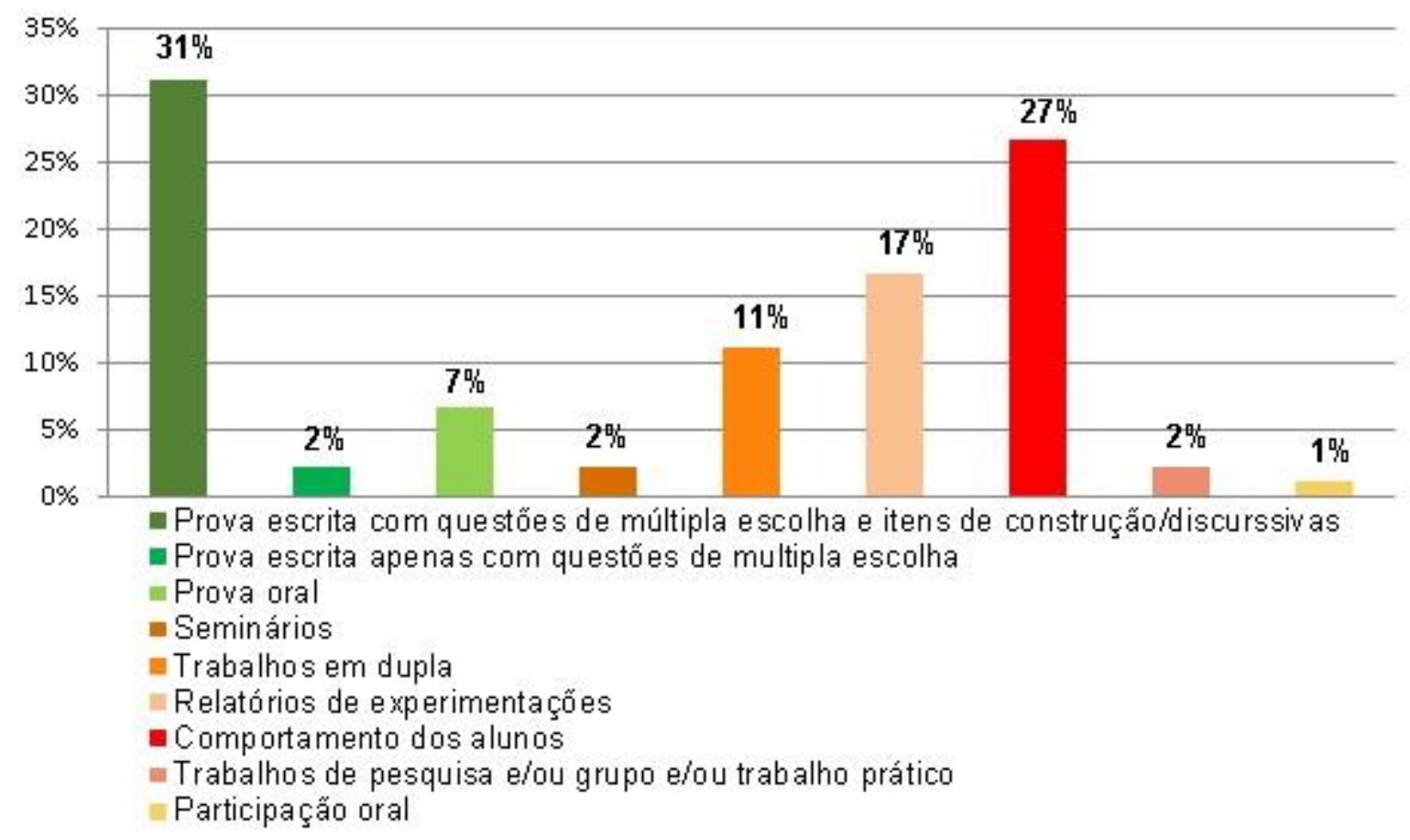

Fonte: elaborado pelas autoras

Este resultado é condizente com os evidenciados no gráfico da figura 8, onde se verifica a preocupação com os elementos (gráficos, tabelas, etc.), com a contextualização, correlação e interdisciplinaridade. Neste contexto, 97\% dos professores também responderam que incorporam, nos instrumentos avaliativos, elementos que permitem diagnosticar as habilidades exigidas nos Exames Nacionais. Uma mesma percentagem (97\%), igualmente elevada, foi obtida para a pergunta "Quando elabora questões para as provas de avaliação, coloca questões do Exame Nacional?"

A preocupação com a avaliação também está demonstrada quando $27 \%$ dos professores mencionam utilizar o feedback "Sempre que participam oralmente" (P12), "Nas sessões de autoavaliação e nas correções dos testes, para além das aulas 


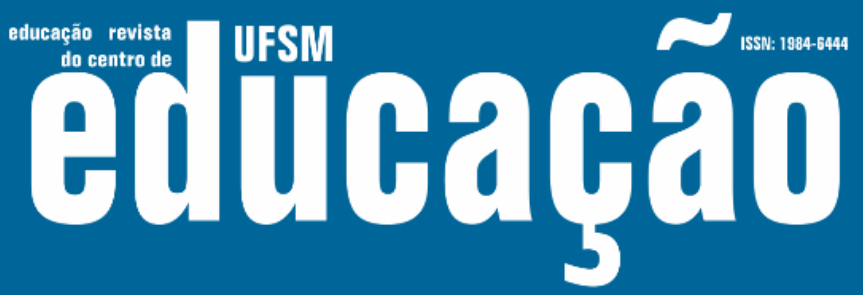

ISSN: 1984-6444 | http://dx.doi.org/10.5902/1984644439560

normais" (P13), "Na oralidade e na avaliação escrita" (P25). Assim, os resultados expressos apontam o feedback associado ao avaliar.

Por outro lado, avaliações em diferentes parâmetros (seminários, fichas formativas, autoavaliação, etc.), não suscetíveis de serem medidas exclusivamente como instrumentos de avaliação escrita, apesar de pouco representativas, demonstram que os professores também estão preocupados em obter não somente uma única medida de desempenho.

\section{Utilização de Livros didáticos}

Os livros didáticos são considerados como uma ferramenta de apoio pedagógico. Entretanto, a sua utilização em sala de aula tem sido muito frequente e assume uma certa centralidade. Portanto, saber com que frequência os livros didáticos fizeram parte dos recursos utilizados, pelos professores, para o desenvolvimento das aulas, é importante para entender, não só suas práticas como também por se tornar uma das principais, se não a única fonte de informações, conceitos, etc.

Em termos de trabalho docente realizado exclusivamente nas salas de aula, perguntou-se com que frequência os livros didáticos faziam parte dos recursos utilizados para o desenvolvimento das aulas. Constou-se que $45 \%$ dos professores fazem uso dos livros todos os dias (figura 10) e $41 \%$ o utilizam entre 1 a 2 vezes por semana. Esses resultados apontam para a importância do livro didático no ensino.

Em Portugal, não existem questões de Exames Nacionais anteriores nos livros didáticos. As editoras investem em livros específicos de preparação para o Exame Nacional. Vale ressaltar que as mesmas editoras que editam os livros didáticos, também editam os livros preparatórios para o Exame Nacional. Por fim, há de se mencionar que Portugal apresenta um sistema de certificação prévia de livros didáticos, regido pela Lei $n .-47 / 2006$. Portanto, a elaboração dos livros é feita em "conformidade com os objetivos e conteúdos do currículo nacional e dos programas e orientações curriculares em vigor" (Art. ${ }^{0} 11 .^{\circ}$ da Lei n. $\left.{ }^{\circ} 47 / 2006\right)$. No entanto, a escolha dos livros se dá através dos agrupamentos escolares ou escolas isoladas, ou seja, há 


\section{Eีtlatẫa}

ISSN: 1984-6444 | http://dx.doi.org/10.5902/1984644439560

diferentes livros sendo utilizados por diferentes escolas. Assim, a utilização dos mesmos pode vir a refletir no desempenho dos alunos nos Exames, levando-se em conta o papel que esse instrumento desempenha no percurso de aprendizagem dos alunos. Mas, essa correlação só poderá ser confirmada através de uma pesquisa específica.

Figura 10: Frequência de uso dos livros didáticos pelos professores

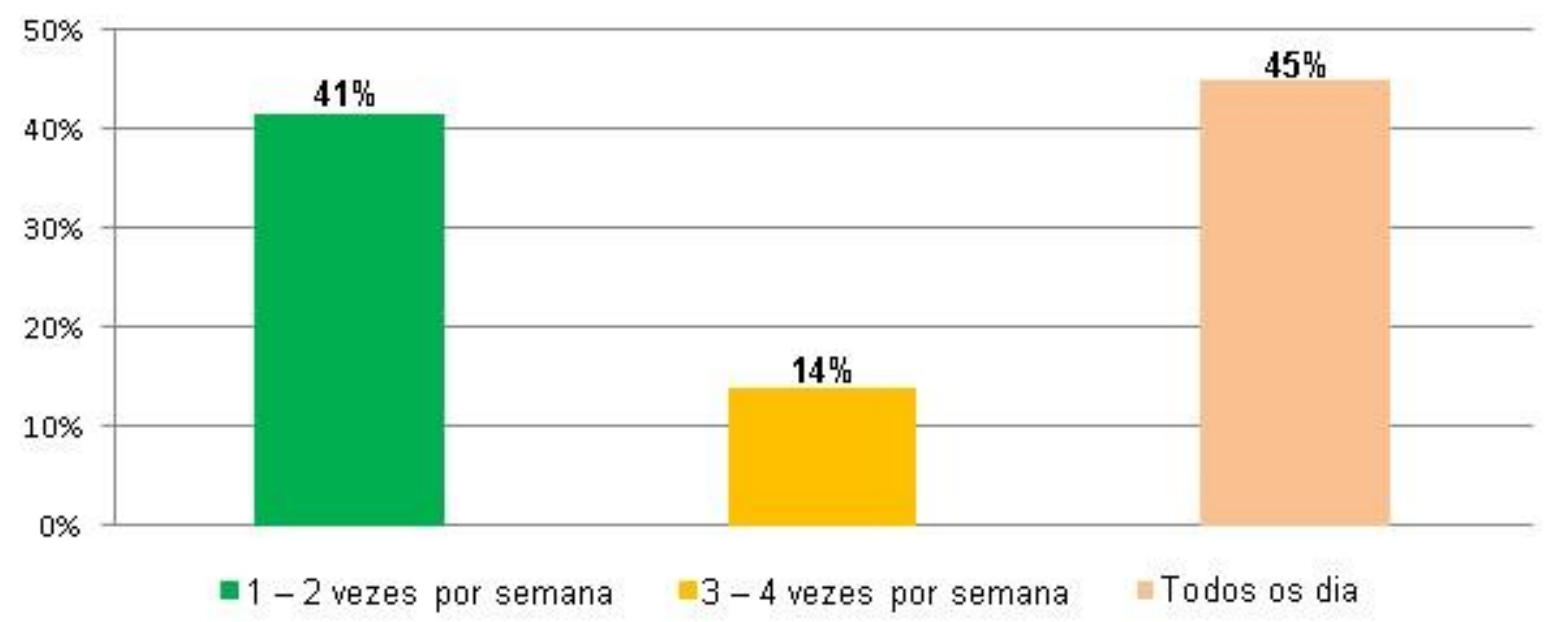

Fonte: elaborado pelas autoras

\section{Preocupação em preparar para o Exame Nacional}

Em relação à preocupação em preparar os alunos para o Exame Nacional, é interessante verificar que, a maioria dos professores (79\%) responderam que não trabalham conteúdos de Biologia especificamente por causa do Exame Nacional. Dos $21 \%$ que admitiram trabalhar conteúdos especificamente por causa do Exame, é possível verificar na figura 11, os critérios utilizados para a sua seleção.

Observando-se a figura 11, constata-se que, entre os critérios apontados, os conteúdos considerados mais difíceis nas últimas provas e os que exigem domínio de conceitos e interpretação de dados científicos são os mais apontados (29\%), seguidos pela escolha dos conteúdos mais recorrentes (24\%). 


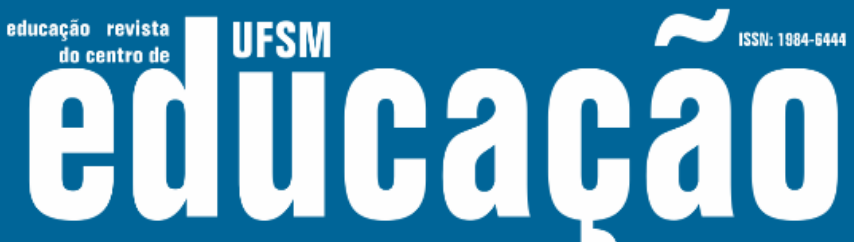

ISSN: 1984-6444 | http://dx.doi.org/10.5902/1984644439560

Figura 11: Critérios utilizados para selecionar os conteúdos trabalhados especificamente por causa do Exame Nacional

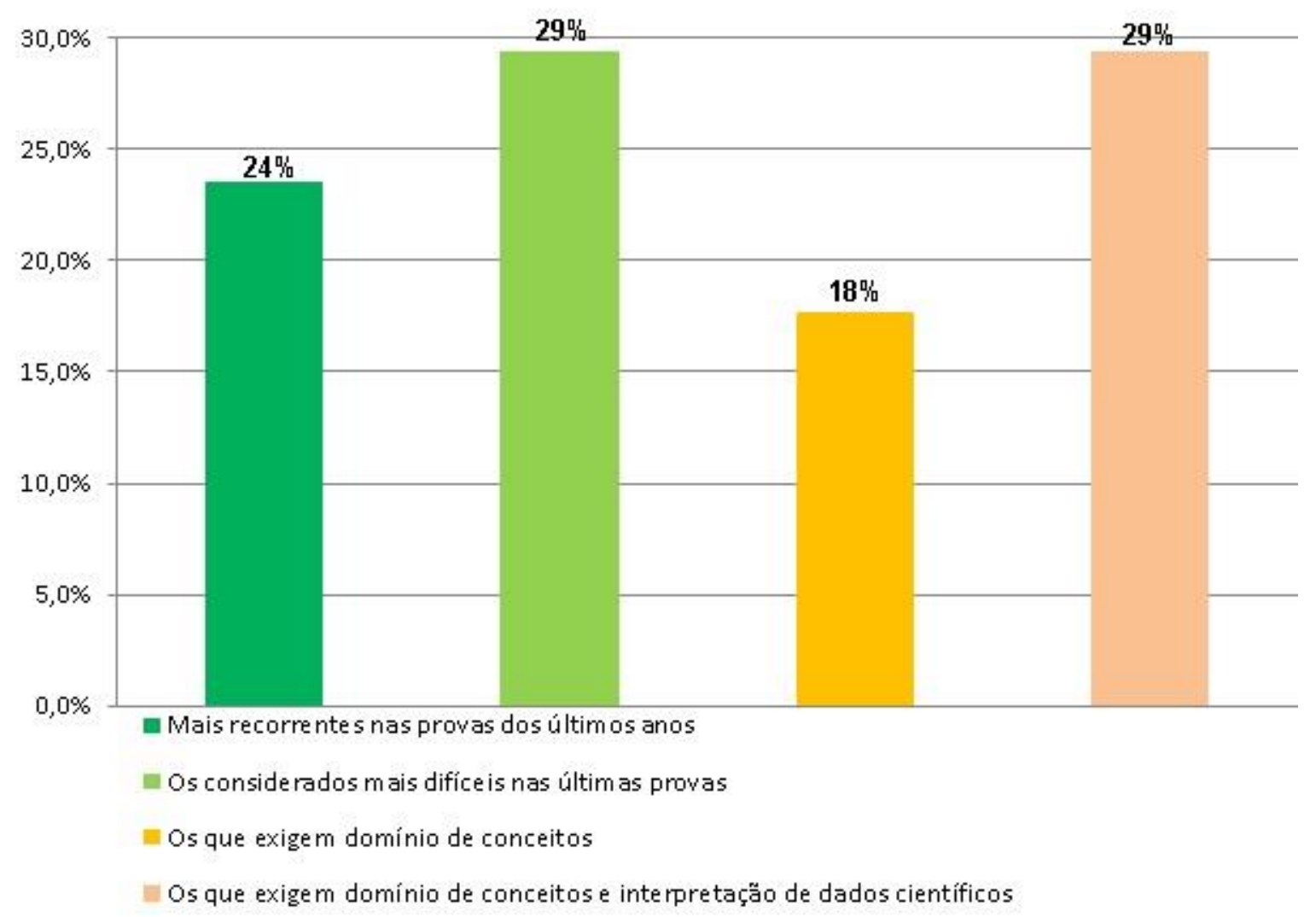

Fonte: elaborado pelas autoras

Acerca desse assunto, dentre os professores que responderam afirmativamente à pergunta sobre trabalhar conteúdos de Biologia especificamente por causa do Exame Nacional, solicitou-se, através de uma pergunta aberta, a identificação desses conteúdos.

Merece destaque a resposta dada pelo professor P6 que menciona "Todos aqueles que, face a um programa, considero relevantes com base na atualização científica e nos próprios conteúdos que o mesmo (programa) refere como "evitar", mas que na realidade são abordados e aprofundados". Neste relato o professor destaca que no programa da disciplina Biologia-Geologia existe a recomendação para evitar certos conteúdos, mas que os mesmos são cobrados no Exame Nacional. Essa percepção demonstra não só seu conhecimento dos princípios orientadores da 


\section{usm Eutibapat

ISSN: 1984-6444 | http://dx.doi.org/10.5902/1984644439560

disciplina como também seu senso crítico em relação a divergência entre as recomendações normativas e a práxis dos Exames Nacionais.

Reportando ao referido programa da disciplina encontra-se a seguinte descrição: "Por motivos pragmáticos, que se prendem com a gestão adequada dos tempos letivos, o programa explicita, também, nesses quadros, os aspectos que devem ser recordados e/ou enfatizados e aqueles que, pelo contrário, devem ser evitados" (MENDES; REBELO; PINHEIRO, 2003, p. 70). Um exemplo das recomendações para "evitar", presente no programa da disciplina Biologia é "Descrição de processos de regulação gênica envolvidos na diferenciação celular" (MENDES, REBELO, e PINHEIRO, 2003, p. 6). Não obstante o que referiu o P6, pode ser verificado na formulação da questão 3 exemplificada na figura 12, demonstrando a refletida divergência

Figura 12: Conhecimentos sobre diferenciação celular presente em questão do Exame Nacional

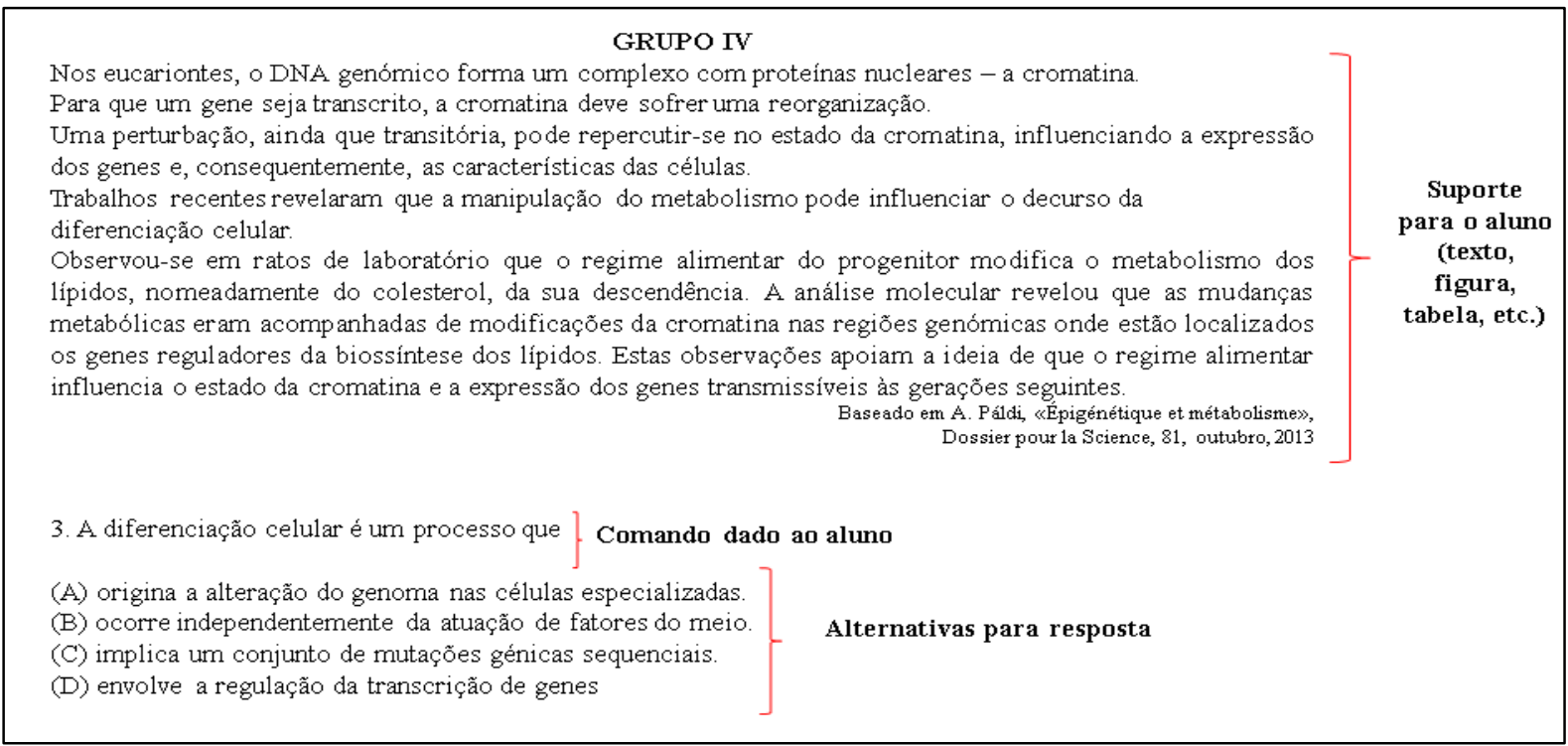

Fonte: Prova BG702, fase 2, versão 1 do Exame Nacional de 2014, questão 3 p.14

A relação existente entre Exames e conteúdos é também considerada pelo professor $\mathrm{P}$ 21, que menciona que a sua abordagem é feita em relação a "Todos (os conteúdos), já que todos constam da matriz de Exame". 


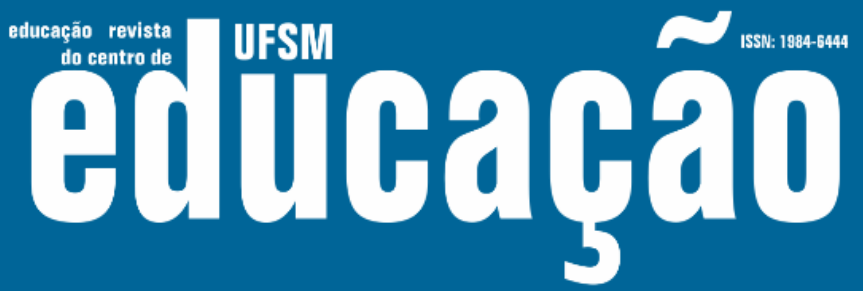

ISSN: 1984-6444 | http://dx.doi.org/10.5902/1984644439560

Importa salientar o fato de ambos professores desta pesquisa revelarem, implícita ou explicitamente, a preocupação com o cumprimento integral do programa da disciplina para atender ao Exame. Parece-nos que este resultado reforça que o conteúdo é visto como algo em relação ao qual não há uma autonomia para a escolha. De fato, Medeiros et al, numa pesquisa em que objetivou analisar as práticas pedagógicas usadas pelos professores de Biologia atuantes no Ensino Secundário da cidade portuguesa de Bragança (Nordeste de Portugal), também verificou a preocupação dos professores em cumprir o programa. Os autores mencionam que "[...] os professores ainda revelaram a preocupação em lecionar todos os conteúdos previstos no currículo, perante a necessidade de os estudantes Portugueses realizarem os Exames Nacionais como processo seletivo para entrada no Ensino Superior." (MEDEIROS et al, 2017, p. 348)

Considerando as atividades proporcionadas pela escola, com o objetivo de preparar os alunos para o Exame Nacional, os professores foram indagados se isso ocorria na escola em que lecionavam. O presente estudo revelou que $69 \%$ das escolas, nas quais os professores entrevistados trabalham, o fazem. Indagados, através de questão aberta, sobre como o fazem, o professor P9 menciona "Gabinete de Apoio aos Exames, a decorrer desde o início do ano letivo", já o P23 "Treino com base em enunciados de Exames de anos anteriores". Existiram ainda respostas como "Aulas de apoio nos 15 dias anteriores ao Exame, já em pausa letiva" professor P19, "Resolução de Exames nacionais" P13 e "Aulas de apoio" P27.

\section{As influências do Enem nos professores de biologia do Brasil}

\section{O que pensam os professores de biologia sobre o ENEM}

Relativamente ao ENEM, questionou-se os professores sobre a sua importância como forma de avaliar o percurso escolar do aluno do ensino médio. $\mathrm{Na}$ figura 13 verifica-se que $81 \%$ dos professores responderam que apenas, em parte, consideram o ENEM como uma boa forma de avaliar o percurso escolar do aluno, $13 \%$ consideraram o Exame uma boa forma e $6 \%$ julgam que o ENEM não é uma boa forma de avaliar o percurso escolar. Esse resultado pode estar relacionado a 


\section{Althapãa}

ISSN: 1984-6444 | http://dx.doi.org/10.5902/1984644439560

percepção dos professores quanto aos conteúdos não contemplados devido ao pequeno número de questões, se comparadas a seleção dos conteúdos e competências que deveriam ser testadas.

Figura13: Importância do ENEM na avaliação do percurso escolar dos alunos brasileiros

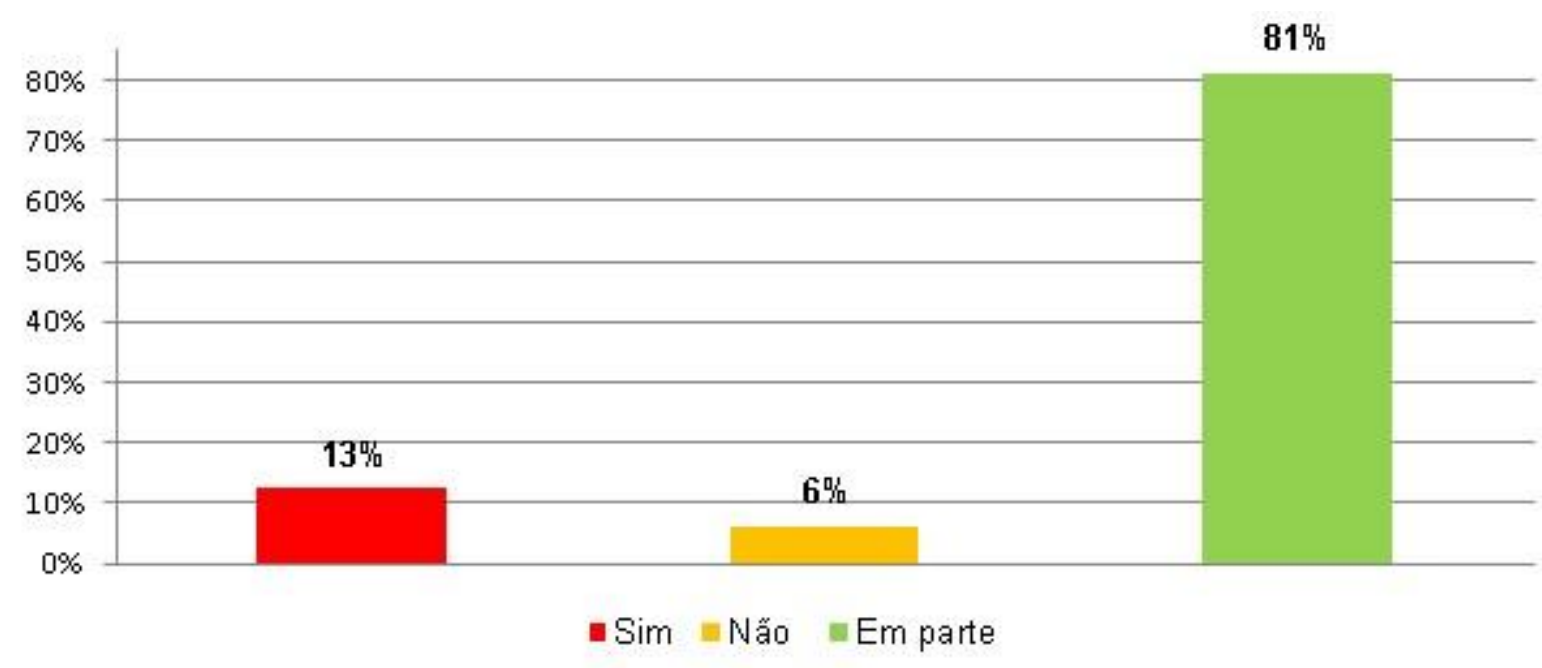

Fonte: elaborado pelas autoras

Intencionando aprofundar o conhecimento acerca da percepção dos professores sobre o ENEM, questionou-se qual a importância do ENEM na formação dos alunos?" As respostas apresentadas na figura 14, mostram que 18\% dos professores consideram que o ENEM ajuda o aluno no acesso a universidade. Esta postura reflete a importância dada pela maioria dos professores ao ENEM por este influenciar o futuro dos alunos, já que determina o processo de seleção destes ao Ensino Superior. As respostas convergem em direção à política pública de ingresso ao Ensino Superior no Brasil, cuja nota do ENEM é utilizada para o ingresso em Instituições de Ensino Superior (IES), através de um sistema de seleção unificada (SiSU), no qual instituições públicas de Ensino Superior oferecem vagas para os candidatos participantes do Exame. Atualmente 126 instituições públicas Brasileiras aceitam a nota do Exame em substituição aos seus vestibulares e 38 estrangeiras (34 em Portugal, 3 na Inglaterra e 1 na França (BRASIL/MEC, [s.d.]). 


\section{DFEM

ISSN: 1984-6444 | http://dx.doi.org/10.5902/1984644439560

As notas do ENEM também são utilizadas para selecionar os estudantes contemplados no Programa Universidade para Todos (Prouni), um programa do Ministério da Educação que concede bolsas de estudo integrais e parciais a estudantes egressos da rede pública (ou da rede privada na condição de bolsista integral) em universidades privadas. A nota do ENEM ainda é utilizada para ajudar estudantes de baixa renda a ter acesso ao Fundo de Financiamento Estudantil do Ensino Superior (Fies).

Figura 14: Opinião dos professores sobre a importância do ENEM na formação dos alunos

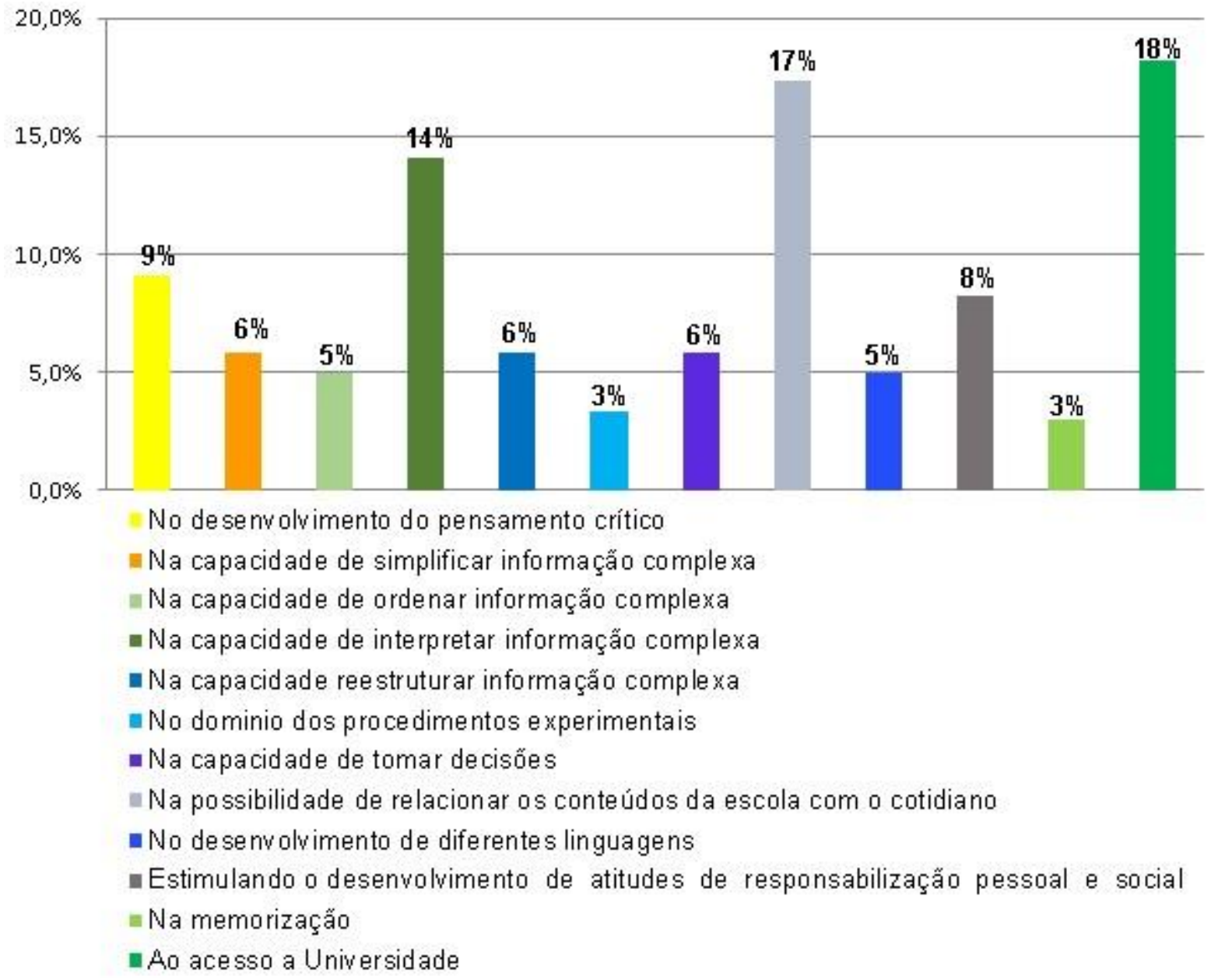

Fonte: elaborado pelas autoras

Dezessete porcento (17\%) de professores consideram também que o ENEM ajuda os alunos a relacionaros conteúdos escolares com o cotidiano. Este resultado 


\section{Fusm Eutlaará

ISSN: 1984-6444 | http://dx.doi.org/10.5902/1984644439560

está provavelmente relacionado com o fato da utilização de questões que têm enfatizado as problemáticas socioambientais da atualidade.

Dos professores indagados 14\% acreditam que o ENEM ajuda os alunos na capacidade de interpretar informação complexa. Provavelmente, esta convicção está relacionada com o fato das provas requererem a interpretação de informações em diferentes formas de linguagem (infográficos, fragmentos de notícias, crônicas e artigos de opinião; textos retirados de jornais) bem como tabelas, gráficos e imagens. Apenas $3 \%$ dos professores responderam que o ENEM ajuda na memorização e no domínio de procedimentos experimentais.

Ainda sobre a percepções dos professores a respeito dos impactos do ENEM, questionou-se sobre a tomada de conhecimento das médias (Rankings) no referido Exame, obtidas pela escola em que lecionavam, especificamente na disciplina de Biologia. Os resultados revelaram que metade dos professores entrevistados (50\%) tomaram conhecimento das médias e a outra metade não tiveram conhecimento das mesmas. Relativamente à opinião dos professores sobre a problemática média divulgada vs. realidade da escola, $53 \%$ dos professores têm a visão de que os rankings não correspondem à realidade da sua escola e $47 \%$ acreditam que sim.

Entre os professores que consideram que os os rankings não correspondem à realidade da sua escola, o professor P21 menciona "Acredito que são muitos fatores envolvidos neste processo, e uma única forma e momento de avaliação não seria suficiente para corresponder à realidade, apenas mostrar uma estimativa temporal". Esta declaração é pertinente quando analisadas as correlações existentes entre as notas e informações socioeconômicas dos candidatos, divulgadas através dos relatórios pedagógicos, elaborados pelo Instituto Nacional de Estudos e Pesquisas Educacionais Anísio Teixeira (Inep). Nestes relatórios, constata-se que há uma grande influência de fatores como diferenças de percursos escolares (escolas públicas ou privadas), renda familiar, sexo, cor/raça, idade, além da região do país em que se localizam as escolas. Com relação a este desempenho, e em relação a localização, o relatório menciona "o melhor resultado de algumas regiões em relação às outras pode ser explicado, em parte, pelas diferenças nos níveis socioeconômicos, fator correlacionado ao desempenho acadêmico" (BRASIL, 2015, p. 202). 


\section{Eutha}

ISSN: 1984-6444 | http://dx.doi.org/10.5902/1984644439560

\section{Práticas e estratégias pedagógicas utilizadas}

Quanto as práticas e estratégias pedagógicas, questionou-se aos professores se eles consideravam que o ENEM promove mudanças ao nível dos processos de ensino e aprendizagem. Para $84 \%$ a resposta foi afirmativa. Entre os que responderam afirmativamente ao questionamento, 31\% mencionaram alterações na organização curricular, na prática do professor (29\%), formulação de competências e objetivos educativos (25\%) e apenas $15 \%$ dos professores mencionaram que as mudanças se deram no processo de aprendizagem dos alunos (figura 15).

Refletindo, a partir da perspectiva dos professores, percebe-se que tanto a organização curricular quanto a prática do professor são fortemente influenciadas pelo ENEM.

Figura 15: Opinião dos professores sobre as mudanças promovidas pelo ENEM ao nível dos processos de ensino e aprendizagem

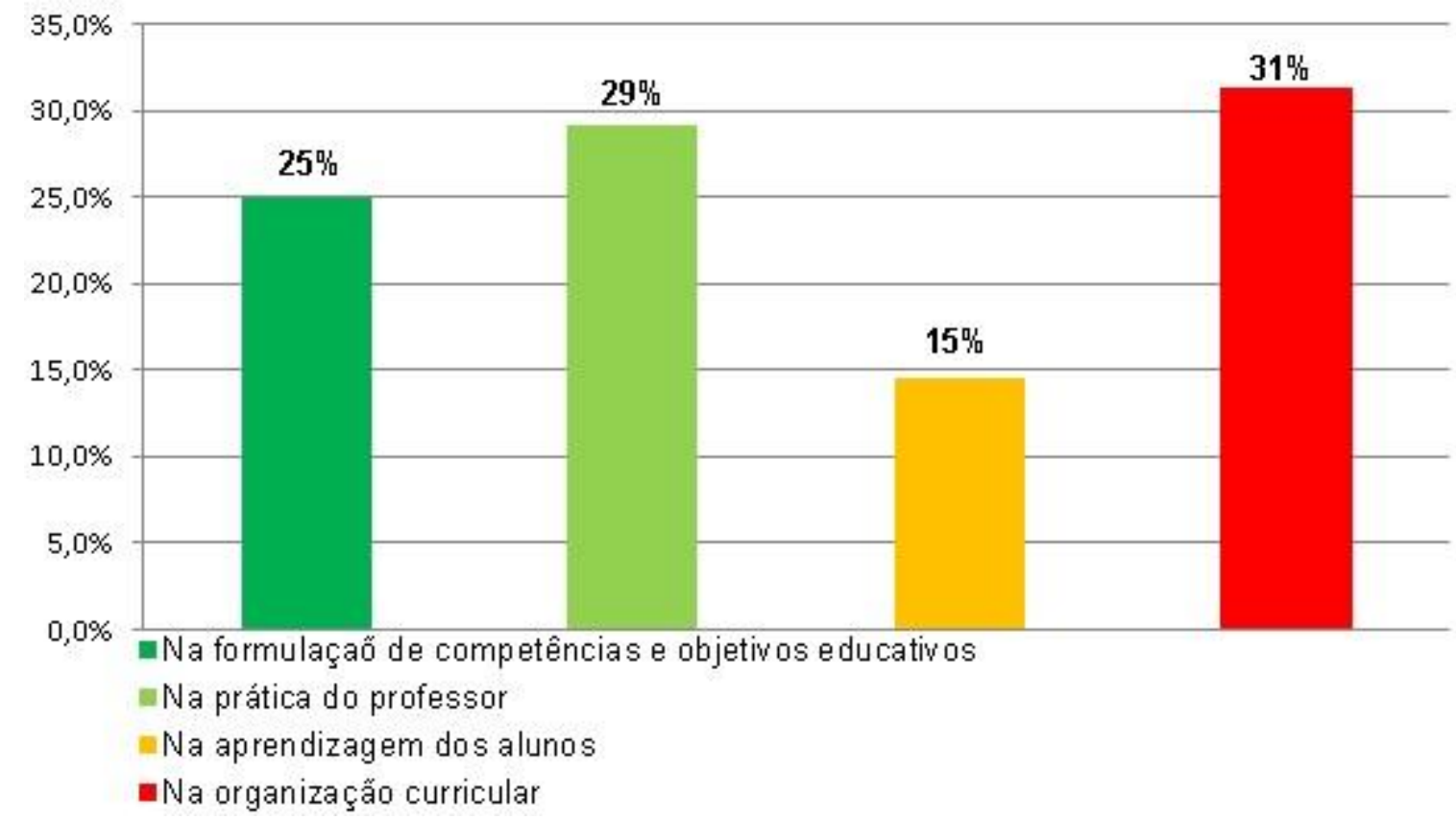

Fonte: elaborado pelas autoras

No Brasil, Base Nacional Comum Curricular (BNCC) do Ensino Médio está organizada por áreas de conhecimento, sendo elas: Linguagens e suas Tecnologias, 


\section{N

ISSN: 1984-6444 | http://dx.doi.org/10.5902/1984644439560

Matemática e suas Tecnologias, Ciências da Natureza e suas Tecnologias, Ciências Humanas e Sociais Aplicadas.

Segundo a BNCC, a área de Ciências da Natureza deve:

"se comprometer com a formação dos jovens para o enfrentamento dos
desafios da contemporaneidade e ensinar aos alunos a interpretação de
fenômenos naturais e processos tecnológicos de modo a possibilitar aos
estudantes a apropriação de conceitos, procedimentos e teorias dos diversos
campos das Ciências da Natureza (BRASII, 2018, p. 537)"

Em cada uma das áreas de conhecimento, há competências e habilidades a serem desenvolvidas. O mesmo ocorre com o ENEM, que através da Matriz de referência, segue estrutura semelhante. Portanto, as respostas dos professores são condizentes com os documentos oficiais que norteiam a prática pedagógica.

Verifica-se também, na figura 15 , que $29 \%$ dos professores admitiram que 0 ENEM promoveu mudanças nas suas práticas. Aos que admitiram essas mudanças, questionou-se a respeito dos aspectos em que elas ocorreram. Dentre os citados estavam a forma de trabalhar os conteúdos na aula com $55 \%$ das respostas (figura 16); seguiu-se o aspecto voltado para o processo de avaliação, com $25 \%$ e escolha dos conteúdos ( $10 \%$ das respostas). Esse mesmo percentual representa a quantidade de professores que mencionam que não houve nenhum tipo de influência por parte do ENEM, nas suas práticas docentes. 


\section{F HW Gutrahấ}

ISSN: 1984-6444 | http://dx.doi.org/10.5902/1984644439560

Figura 16: Opinião dos professores sobre como o ENEM exerce influência na sua prática docente

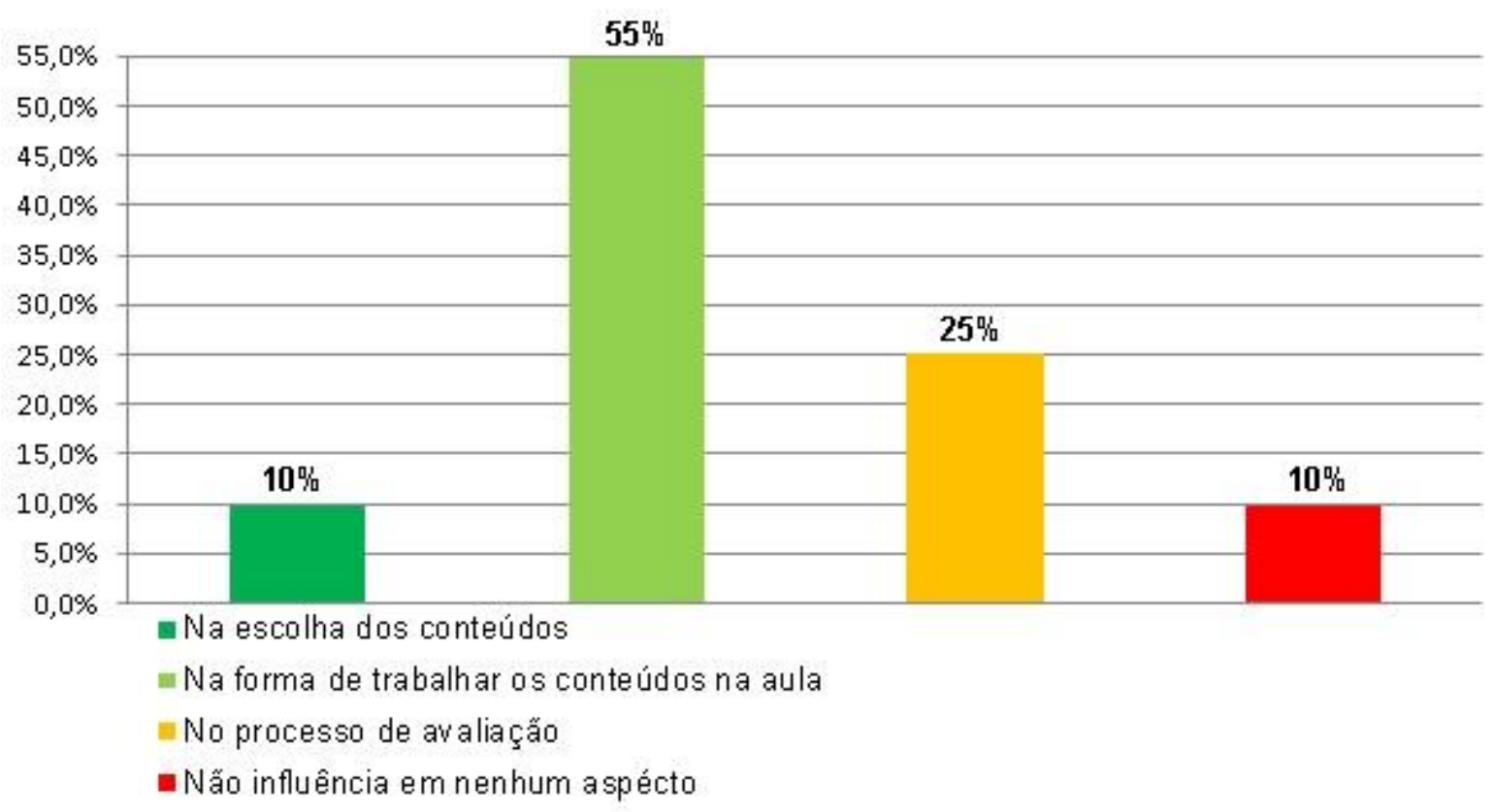

Fonte: elaborado pelas autoras

Outro aspeto que reforça o mencionado no parágrafo anterior foi confirmado com a análise das respostas obtidas ao questionamento "utiliza, em sala de aula, questões do ENEM como método de ensino e no intuito de prepará-los a participarem do Exame?" De acordo com os resultados, 78\% dos professores respondentes admitiram utilizar (figura 17). Apenas $22 \%$ disseram não utilizar esta prática.

Figura 17: Percentagem de professores que admitiram utilizar, em sala de aula, questões do ENEM como método de ensino e preparação para o Exame

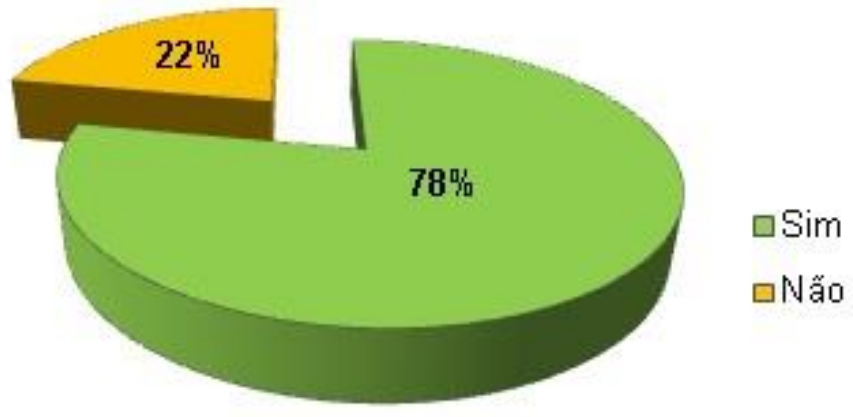

Fonte: elaborado pelas autoras 


\section{工 Wism

ISSN: 1984-6444 | http://dx.doi.org/10.5902/1984644439560

Levando-se em conta que para solucionar as questões do ENEM, os alunos necessitam muito mais do que apenas a memorização de conceitos; demanda a interpretação e leitura de dados é, portanto, um conhecimento que carece ser ensinado de forma mais ativa. Nesta perspectiva, e fazendo uma apreciação dos resultados obtidos na figura 16 , onde se verifica que mais da metade dos professores mudaram a forma de trabalhar os conteúdos, é possível inferir que o ENEM está afetando não só o que é ensinado nas escolas no Brasil, como também como se está ensinando.

$\mathrm{Na}$ análise dos aspetos das práticas avaliativas (figura 18) que mudaram devido ao ENEM, 27\% dos respondentes afirmaram que mudou em termos de exigências, $25 \%$ referem procurar correlacionar os conteúdos de forma interdisciplinar e contextualizada e, empatados com $21 \%$, alegaram haver alterações na formulação das provas. A inclusão de mais elementos (gráficos, tabelas, figuras) nas provas e instrumentos avaliativos que levam o aluno a interpretar, correlacionar, e expressar os conhecimentos adquiridos na disciplina são algumas das alterações referidas. Apenas $6 \%$ dos respondentes disseram ter mudado suas práticas avaliativas em termos de conteúdos exigidos.

Figura18: Mudanças nas práticas avaliativas devido ao ENEM

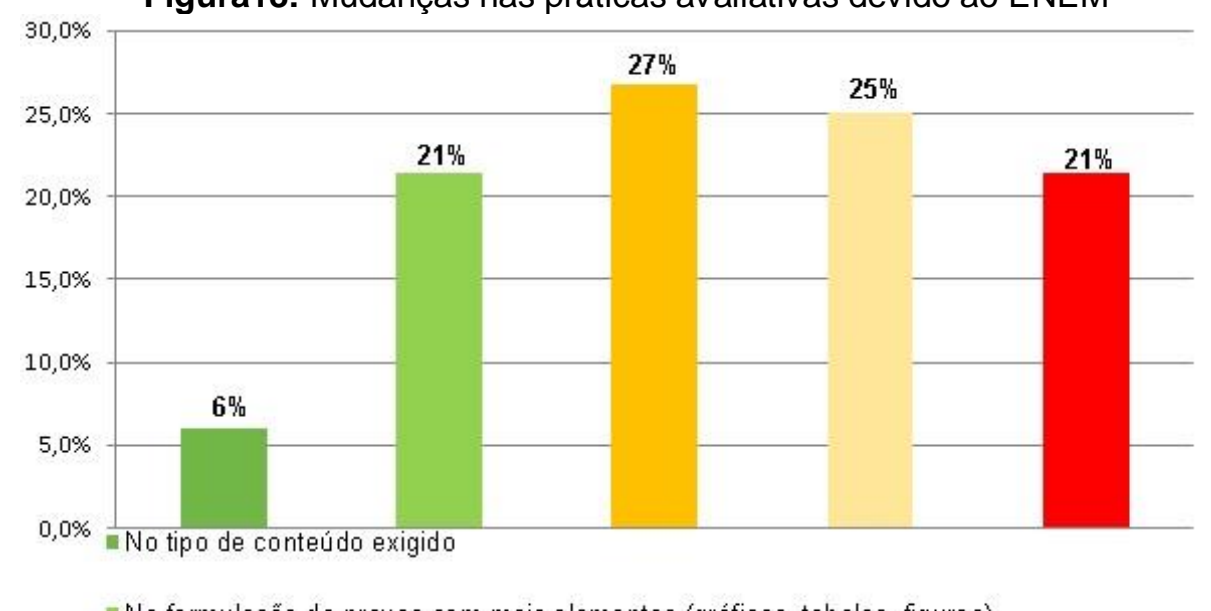

"Na formulaçẫo de provas com mais elementos (gráficos, tabelas, figuras)

- No nível de exigência (exemplo: provas mais elaboradas, exigindo do aluno mais raciocínio ou mais correlaçẫo entre conceitos e fenômenos naturais)

Procura correlacionar os conteúdos de forma interdisciplinar e contextualizada

- Elabora instrumentos avaliativos que levam o aluno a interpretar, correlacionar, e expressar seus conhecimentos adquiridos na disciplina

Fonte: elaborado pelas autoras 


\section{Ej|lिa \\ ISSN: 1984-6444}

ISSN: 1984-6444 | http://dx.doi.org/10.5902/1984644439560

Quanto aos instrumentos utilizados para avaliar os alunos (figura 19), os professores descreveram uma variedade relativamente grande de meios de avaliação. Os resultados demonstram que os professores têm uma preferência por provas escrita com questões de múltipla escolha e questões discursivas, preferência que foi expressa por $23 \%$ dos respondentes. Em seguida, os seminários foram citados por $21 \%$ dos participantes, sendo o segundo instrumento avaliativo mais utilizado. Trabalhos em dupla, relatórios de experimentações e comportamento dos alunos (entrega os trabalhos nas datas marcadas, é organizado, responde aos questionamentos, participa nas aulas) obtiveram $18 \%, 17 \%$ e $16 \%$ respetivamente. $\mathrm{Na}$ escala de respostas menos expressivas verificamos, empatadas com $2 \%$, prova escrita apenas com questões de múltipla escolha e prova escrita apenas com questões discursivas. A prova oral foi sem dúvida o instrumento menos utilizado, com $1 \%$ apenas de citações.

Figura 19: Práticas avaliativas utilizadas pelos professores

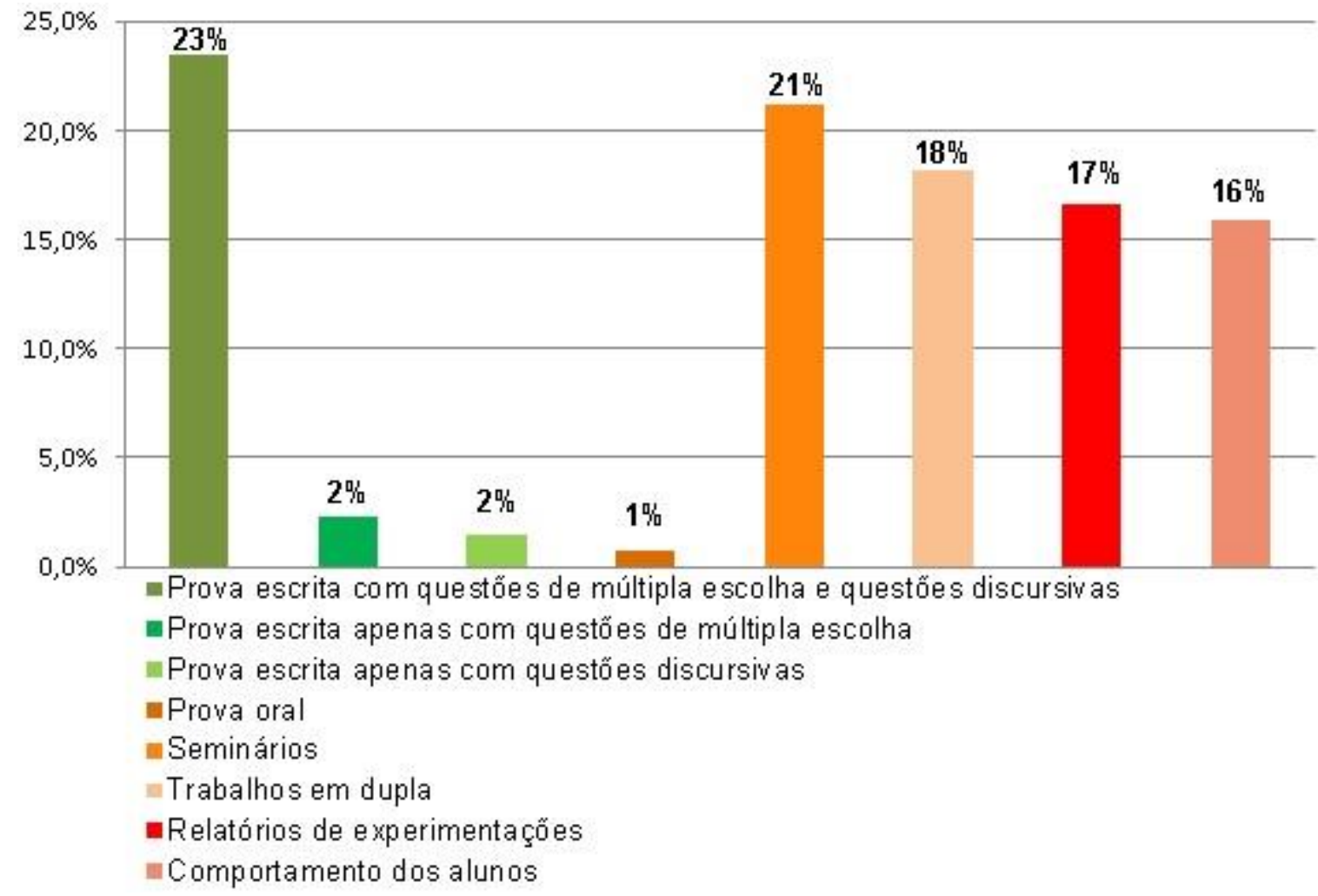

Fonte: elaborado pelas autoras 


\section{Autดaคูão}

ISSN: 1984-6444 | http://dx.doi.org/10.5902/1984644439560

Por outro lado, a utilização do feedback pelos professores brasileiros parece estar ligada a um conceito equivocado, pelo menos no sentido de retroagir, ou seja, de agir novamente para proporcionar reforço ou alteração da aprendizagem de algo que não foi bem aprendido. Isso porque, $97 \%$ professores respondeu que fazia parte de sua prática pedagógica o feedback, mas a ênfase dada pelos respondentes quando questionados "Em que momento utiliza o feedback? é o de associação ao uso privilegiado dos resultados obtidos nos processos avaliativos. Apenas 3\% professor mencionou utilizar em todos os momentos, $97 \%$ afirmaram utilizar "Após as provas; após os exercícios; após apresentações dos alunos (seminários, explanações, etc.)". E alguns responderam que "Anterior e posterior as avaliações revisando sempre o conteúdo." (P23) e "Em qualquer tipo de avaliação" (P24). O único instrumento não suscetível de ser considerado exclusivamente como instrumento de avaliação escrita foi o seminário.

\section{A utilização de livros didáticos}

$\mathrm{Na}$ figura 20 pode-se observar que $63 \%$ dos professores fazem uso dos livros didáticos de uma a duas vezes por semana, $28 \%$ admitem utilizá-los todos os dias e $9 \%$ fazem uso de três a quatro vezes por semana. Se somarmos os que utilizam de uma a duas vezes com os que usam todos os dias teremos $91 \%$ dos professores fazendo o uso deste recurso e, portanto, utilizando-os como um guia de suas práticas didático-pedagógicas e não como um apoio. Essa constatação preocupa, pois, ao utilizar o livro com tanta frequência os professores podem estar, dentre outras coisas, diminuindo a construção de certas habilidades cognitivas em seus alunos. Além de que, muitos livros apresentam conceitos diferentes para o mesmo assunto, gerando constrangimentos em termos de desempenho dos alunos, no contexto de avaliação externa.

No Brasil, os livros didáticos são editados com inúmeras questões do ENEM de anos anteriores, o que estimula ainda mais o seu uso. 


\section{DF HEM Gutrathá}

ISSN: 1984-6444 | http://dx.doi.org/10.5902/1984644439560

Figura 20: Frequência de uso dos livros didáticos pelos professores

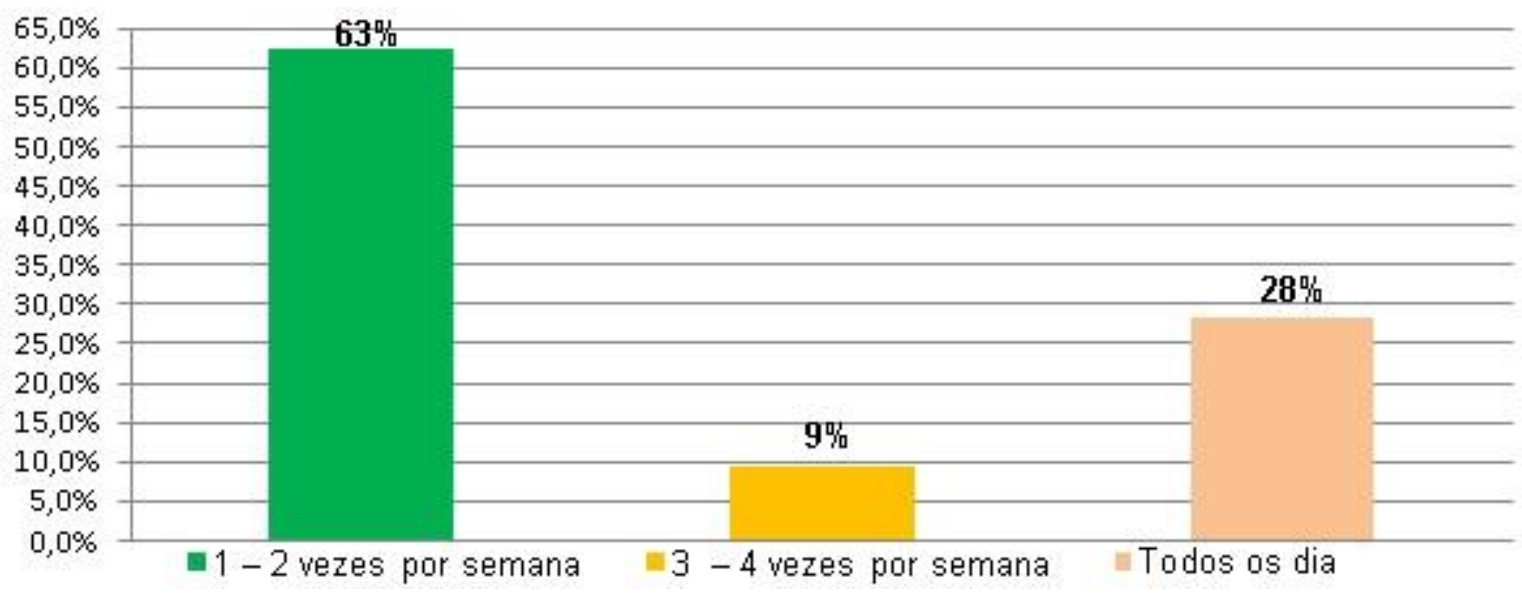

Fonte: elaborado pelas autoras

\section{Preocupação de professores e Escolas em preparar para o ENEM}

O ENEM tem grande importância na vida dos estudantes brasileiros e os professores estão atentos a isso. Mas, esses mesmos professores trabalham conteúdos de Biologia, especificamente por causa do ENEM? As respostas predominantes foram que $75 \%$ não têm essa preocupação enquanto $25 \%$ manifestaram essa preocupação. Esse resultado parece demonstrar uma certa incoerência e/ou contradição por parte dos professores, pois, 78\% destes (figura 17), respondeu que utilizaram questões do ENEM em sala de aula como método de ensino e no intuito de prepará-los a participarem do Exame. No entanto, o resultado não é incoerente; basta constatar que, no primeiro questionamento, o objetivo foi solicitar informações sobre um fato (utilizam ou não questões do ENEM como método de ensino), já no outro questionamento o objetivo era solicitar informações a respeito de valores (trabalhar conteúdos de Biologia, especificamente por causa do ENEM?).

Quanto à valoração do ENEM para organizar o conteúdo a ser ensinado, mencionaram "São trabalhados todos os conteúdos previstos porém, reforçamos o que é mais cobrado no ENEM mencionando a importância de se estudar mais e ler mais." (P5); "Trabalho os conteúdos da ementa da disciplina, dando enfoque em alguns que são bastante cobrados no Enem."(P9). Dois outros depoimentos dos 


\section{Usm Eutoabुa}

ISSN: 1984-6444 | http://dx.doi.org/10.5902/1984644439560

professores refletiram sobre a questão da carga horária versus conteúdo, sendo eles: "Trabalho de acordo com as ementas do curso e frequentemente há sobreposição ao ENEM. Não incluo conteúdos para preparar os alunos para o ENEM (a carga horária mal atende a ementa, não é possível incluir mais conteúdos" - P10). e "Diante da falta de tempo, priorizo conteúdos em detrimento de outros. Costumo dar ênfase a temas atuais (p. ex. Zika e microcefalia em 2017) e não trabalhar conteúdos isolados, que costumeiramente não caem no ENEM (p. ex. histologia)." (P27). Por sua vez, os que afirmaram trabalhar conteúdos de Biologia, especificamente por causa do ENEM, referem que trabalham temas como: "Ecologia, sustentabilidade, evolução, problemas ambientais" (P29), "Ecologia, Fisiologia e Histologia, Citologia, Genética e Biotecnologia, Microbiologia e Parasitologia" (P1).

A figura 21 demonstra os critérios mais utilizados para selecionar os conteúdos a serem trabalhados em função do ENEM. Constata-se que aqueles que exigem domínio de conceitos e interpretação de dados científicos foram os mais mencionados com $45 \%$ de frequência, seguidos dos mais recorrentes, com $22 \%$. Empatados, com $10 \%$ da frequência, ficaram os considerados mais difíceis nas últimas provas e os que exigem domínio de conceitos. Cabe ressaltar que $13 \%$ dos professores admitiram usar, como critério, a sugestão dos alunos.

Figura 21: Critérios utilizados para selecionar os conteúdos trabalhados especificamente por causa do ENEM.

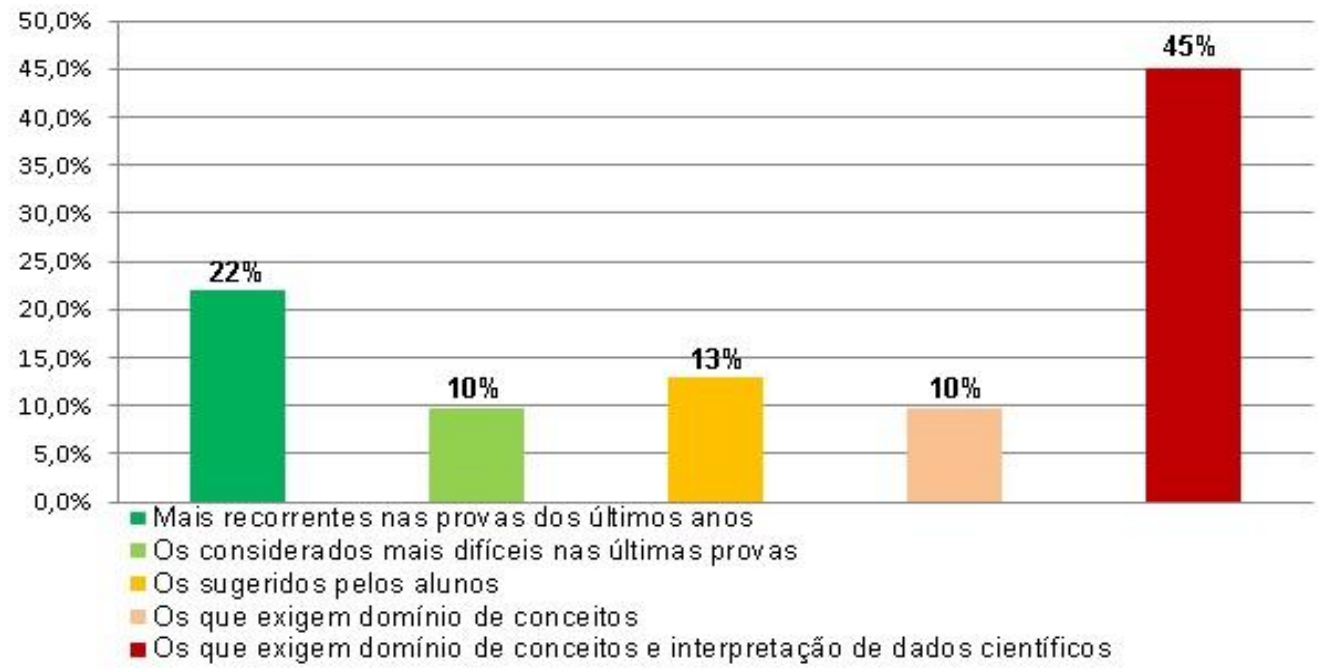

Fonte: elaborado pelas autoras 


\section{N

ISSN: 1984-6444 | http://dx.doi.org/10.5902/1984644439560

Cabe ressaltar que $45 \%$ dos professores dizem utilizar o critério "os que exigem domínio de conceitos e interpretação de dados científicos" para selecionar os conteúdos a serem trabalhados. As figuras 22 e 23 exemplificam as questões do ENEM que solicitam do aluno domínio de conceitos e interpretação de dados científicos.

Figura 22: Questão que solicita domínio de conceitos e interpretação de dados científicos no ENEM

(52 amarelo) Um pesquisador investigou o papel da predação por peixes na densidade e tamanho de suas presas, como possivel controle de populações de espécies exóticas em costões rochosos. No experimento colocou uma tela sobre uma área da comuni dade, impedindo o acesso dos peixes ao alimento, e comparou o resultado com uma área adjacente na qual os peixes tinham acesso livre. O quadro apresenta os resultados encontrados após 15 dias de experimento:

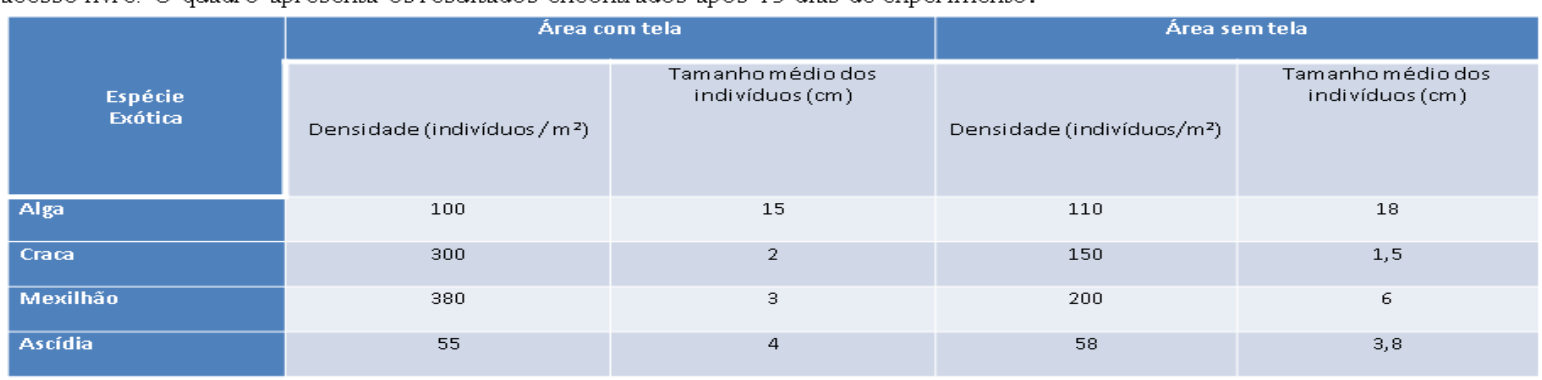

O pesquisador concluiu corretamente que os peixes controlam a população dos(as):

(A) Algas, estimulando o crescimento

(B) Cracas, predando especialmente animais pequenos

(C) Mexilhões, predando especialmente animais pequenos.

(D) Quatro espécies testadas, predando indivíduos pequenos

(E) Ascídias, apesar de não representares os menores indivíduos.

Fonte: Prova ENEM - Ciência da Natureza, caderno de prova amarelo, 2016, p.18.

Figura 23: Questão que solicita domínio de conceitos e interpretação de dados científicos no ENEM

(58 - Amarelo) Um pesquisador percebe que o rótulo de um dos vidros em que guarda um concentrado de enzimas digestivas está ilegivel. Ele não sabe qual enzima o vidro contém, mas desconfia de que seja uma protease gástrica, que age no estômago digerindo proteínas. Sabendo que a digestão no estômago é ácida e no intestino é básica, ele monta cinco tubos de ensaio com alimentos diferentes, adiciona o concentrado de enzimas em soluções com pH determinado e aguarda para ver se a enzima age em algum deles.

O tubo de ensaio em que a enzima deve agir para indicar que a hipótese do pesquisador está correta é aquele que contém

A) cubo de batata em solução $\mathrm{com} p H=9$

B) pedaço de carne em solução $\mathrm{com} \mathrm{pH}=5$

C) clara de ovo cozida em solução $\mathrm{com} \mathrm{pH}=9$

D) porção de macarrão em solução $\mathrm{com} \mathrm{pH}=5$

E) bolinha de manteiga em solução com $\mathrm{pH}=9$

Fonte: Prova ENEM-CN, caderno de prova amarelo, 2014, p.21. 


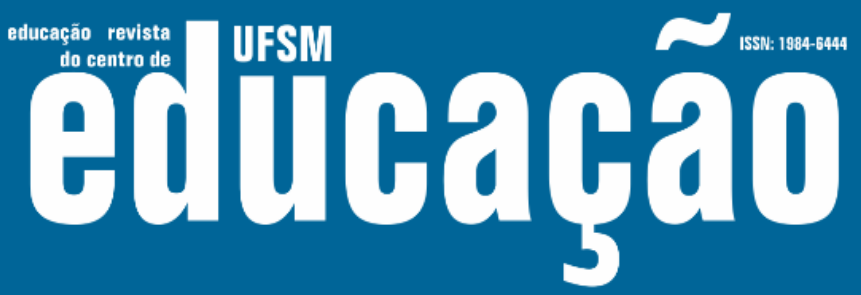

ISSN: 1984-6444 | http://dx.doi.org/10.5902/1984644439560

Em termos de atividades proporcionadas pela escola com o objetivo de preparar os alunos para o ENEM, os professores foram indagados se isso ocorria na escola em que lecionavam. O presente estudo revelou que $81 \%$ das escolas nas quais os professores entrevistados trabalham não o fazem e 19\% têm alguma prática pedagógica exercida com este intuito.

Os professores que afirmaram existir esta prática, foram indagados, através de questão aberta, sobre como ocorrem essas práticas. Apenas 3 professores responderam ao questionamento. O professor P9 menciona "Aulas específicas para Enem, à noite, fora do horário normal de aula, uma vez por semana"; já o P18 afirma que "Existe, mesmo que iniciado só agora em 2018, um curso pré-ENEM ministrado aos alunos de $3^{\circ}$ ano, que manifestem esta vontade, onde os professores resolvem algumas questões de Enem dos anos anteriores" e P23, "Simulados".

\section{Considerações Finais}

Em se tratando de práticas pedagógicas, constatou-se que tanto no Brasil quanto em Portugal, no período analisado por esta pesquisa, a maioria dos professores acreditam que os Exames Nacionais conseguem apenas, em parte, avaliar o percurso escolar do aluno. Entretanto, esses mesmos professores, atribuem aos Exames nacionais algumas capacidades, sendo elas:

Portugal - O Exame Nacional teria a capacidade de ajudar os alunos na capacidade de interpretar, reestruturar e simplificar informações complexas, e de auxiliar os alunos no acesso a Universidade.

Brasil - O ENEM teria a capacidade de ajudar os alunos no acesso à universidade, na possibilidade de relacionar os conteúdos da escola com o cotidiano e na capacidade de interpretar informação complexa.

Parte expressiva dos professores portugueses respondeu que houve mudanças nas suas práticas pedagógicas e na formulação de competências e objetivos educativos em virtude do Exame Nacional. Já os professores brasileiros acreditam que o ENEM promoveu mudanças na organização curricular e na prática pedagógica. A percepção de onde os Exames (Exame Nacional e ENEM) 


\section{Autดaคูão}

ISSN: 1984-6444 | http://dx.doi.org/10.5902/1984644439560

promoveram mudanças está, muito provavelmente, relacionada com as realidades distintas de ambos os países em relação as suas políticas educacionais. Alguns exemplos são: autonomia das escolas em Portugal versus centralidade de decisões no Brasil; escolas agrupadas em Portugal versus escolas isoladas no Brasil e, avaliação externa (Exame Nacional) representando $30 \%$ do valor da nota final do aluno do ensino secundário em Portugal, enquanto no Brasil não existe nenhuma correlação entre as notas do ENEM e as disciplinas do ensino médio. Contudo, as respostas são muito semelhantes quanto ao tipo de mudanças que promoveu. Tal demonstra que, em ambos os países, os professores percebem o Exame como instrumento normalizador tanto da prática pedagógica quanto de um tipo de formação académica padronizada, com um currículo desenhado para determinados conteúdos.

Em relação à preocupação em preparar os alunos para os Exames, em ambos países, a maioria dos professores relataram não trabalhar conteúdos específicos de Biologia com tal propósito, tendo, isso sim, uma preocupação em cumprir a recomendação existente no programa da disciplina. Apesar de não haver uma preocupação específica dos professores em preparar os alunos para os Exames, verificou-se através dos resultados que houve algum tipo de preparação, como aulas de apoio fora do horário das aulas letivas, uso de questões dos Exames, simulados, etc. Independente da forma como ocorrem essas preparações, é importante salientar que elas ocorrem e que, para tal, é necessário mobilizar professores, material, espaço físico e equipes técnicas nas escolas; ou seja, a realização dos Exames (Exame Nacional e ENEM) têm importantes implicações para todos os envolvidos no processo, direta ou indiretamente.

Diante de todo o contexto levantado, ficou evidente que os "Exames em larga escala", tanto de Portugal quanto no Brasil, impactam sobre as práticas de ensino e avaliação dos professores da disciplina Biologia. 


\section{TH Wu Eutlagha}

ISSN: 1984-6444 | http://dx.doi.org/10.5902/1984644439560

\section{Referências}

BRASIL. Ministério da Educação (MEC). Instituto Nacional de Estudos e Pesquisas Educacionais Anísio Teixeira (Inep). Relatório pedagógico: Enem 2011-2012. Brasília, DF: Inep, 2015. $236 \quad$ p.. $\quad$ Disponível em: http://portal.inep.gov.br/documents/186968/484421/Relat\%C3\%B3rio+Pedag\%C3\% B3gico+Enem+2011-2012/b29257e3-2a6c-44a3-992a-02130c379ba9?version=1.1 Acesso em: 26 nov 2018.

BRASIL . Base Nacional Comum Curricular. Ensino Médio. Brasília: MEC. 2018. Disponível em: http://basenacionalcomum.mec.gov.br/images/BNCC_EI_EF_110518_versaofinal_sit e.pdf .Acesso em: 01de junho 2018.

BRASIL. Ministério da Educação (MEC). Conhecendo o Sisu. Disponível em: http://sisu.mec.gov.br/tire-suas-duvidas\#conhecendo. Acesso em: 20 dez. 2018.

FLORES, Maria Assunção. Da necessidade de aprofundar o debate sobre currículo e avaliação. In: Práticas e discursos sobre currículo e avaliação. Santo Tirso: De Facto Editores, 2017. p. 7-22.

INEP. Portaria No 109/2009, de 27 de maio de 2009. Diario Oficial da União, nº 100, de 28 de maio de 2009, Seção 1, pág. 56.Brasília: DF. 2009.

LEMOS, Paulo; RIBEIRO, Salomé; ROCHA, Júlio "Mas, esta prova não avalia conhecimentos!" - O (des)interesse pelos Exames Nacionais. Revista de Educação Geográfica | U.P., v. 1, p. 35-47, 2017. Disponível em http://ojs.letras.up.pt/index.php/GETUP/article/view/1906/1991 Acesso em:10 abril 2018.

MARINHO, Paulo; FERNANDES, Preciosa; LEITE, Carlinda. A avaliação da aprendizagem: da pluralidade de enunciações à dualidade de concepções. Acta Scientiarum. Education, v. 36, n. 1, p. 151, 20 fev. 2014. doi: 10.4025/actascieduc.v36i1.21018. Disponível

em: https://core.ac.uk/download/pdf/143397516.pdf. Acesso em:04 julho 2018

MARQUES, Ana Isabel. et al. Processo de Avaliação Externa da Aprendizagem Provas de Aferição, Provas Finais e Exames Nacionais 2017.Lisboa, 2018. Disponível

em: https://www.dge.mec.pt/sites/default/files/JNE/relatorio_anual_do_jne_2017_final.pdf . Acesso em 22 fevereiro 2019.

MEDEIROS, Francisca Valkiria Gomes de et al. Análise da práxis docente em Biologia no ensino secundário português. Ciênc. educ. (Bauru), Bauru, v. 23, n. 2, p. 341-356, jun. 2017.

Disponível

em http://www.scielo.br/scielo.php?script=sci_arttext\&pid=S1516-

$73132017000200341 \&$ lng=pt\&nrm=iso. Acesso em 10 abril 2018. 


\section{usm Fillaghat}

ISSN: 1984-6444 | http://dx.doi.org/10.5902/1984644439560

MENDES, Alcina; REBELO, Dorinda; PINHEIRO, Eduardo. Programa de Biologia e Geologia 10. ano. Disponível em: http://www.dge.mec.pt/sites/default/files/Secundario/Documentos/Documentos_Disci plinas_novo/Curso_Ciencias_Tecnologias/Biologia_Geologia/biologia_geologia_10.p df Acesso em: 22 jun. 2016.

PORTUGAL. Decreto-Lei n.o 17/2016, de 4 de abril do Ministério da Educação e Ciência (2016). Diário da República, $1^{\text {a }}$ série - No65.

\section{Correspondência}

Daisy da Silva - Instituto Federal de Educação, Ciência e Tecnologia Catarinense - Rua das Missões, 100, Ponta Aguda, CEP 89051000, Blumenau, Santa Catarina, Brasil.

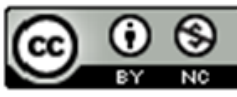

This work is licensed under a Creative Commons Attribution-NonCommercial 4.0 International (CC BY-NC 4.0) 